Florida International University FIU Digital Commons

$7-1990$

\title{
In search of the fair jury: does extended voir dire remedy the effects of pretrial publicity?
}

Hedy Red Dexter

Florida International University

DOI: $10.25148 /$ etd.FI14062257

Follow this and additional works at: https://digitalcommons.fiu.edu/etd

Part of the Legal Studies Commons, and the Psychology Commons

\section{Recommended Citation}

Dexter, Hedy Red, "In search of the fair jury : does extended voir dire remedy the effects of pretrial publicity?" (1990). FIU Electronic Theses and Dissertations. 2787.

https://digitalcommons.fiu.edu/etd/2787 


\section{ABSTRACT}

IN SEARCH OF THE FAIR JURY:

\section{DOES EXTENDED VOIR DIRE REMEDY THE EFFECTS}

OF PRETRIAL PUBLICITY?

by

Hedy Red Dexter

The present study asked two important questions: Does prejudicial pretrial publicity produce bias which may impair juror objectivity and, if it does, can voir dire remedy its untoward effects? Subjects were 68 college undergraduates whose political attitudes had been assessed and who had or had not read case-specific pretrial publicity one week before viewing a murder trial. Trial proceedings took place at the University of Miami law school. Voir dire, trial viewing, and deliberations were conducted in UM's moot courtroom. As predicted, analyses revealed main effects for both voir dire and pretrial publicity such that pretrial publicity increased conviction rate and the extended voir dire decreased conviction rate, but the extended voir dire failed to reduce the specific prejudicial effect of pretrial publicity. These findings suggest that prejudgment of a general nature (e.g., confusion about legal concepts) may be neutralized by an extended voir dire but that prejudice specifically created by exposure to inflammatory news stories is not offset by an extended voir dire format. There is reason to believe, however, that with more time spent explaining case facts and with greater attention to individual jurors, voir dire could eliminate even the specific prejudice created by pretrial publicity.

Brian L. Cutler, Ph.D.

Major Professor 
IN SEARCH OF THE FAIR JURY:

DOES EXTENDED VOIR DIRE REMEDY THE EFFECTS

OF PRETRIAL PUBLICITY?

by

Hedy Red Dexter

A dissertation submitted in partial fulfillment of the requirements for the degree of

DOCTOR OF PHILOSOPHY

in

PSYCHOLOGY

at

FLORIDA INTERNATIONAL UNIVERSITY

Committee in Charge:

Professor Brian L. Cutler, Chairperson

Professor Gary Moran

Professor Ronald Fisher

Professor Paul Foos

Professor Barry Crown

Professor Peter Craumer 
To Professors: Brian L. Cutler, Ph.D.

Gary Moran, Ph.D.

Ronald Fisher, Ph.D.

Paul Foos, Ph.D.

Barry Crown, Ph.D.

Peter Craumer, Ph.D.

This dissertation, having been approved in respect to form and mechanical execution, is referred to you for judgment upon its substantial merit.

Arthur Herriott, Acting Dean

College of Arts and Sciences

The dissertation of Hedy Red Dexter is approved.

Brian L. Cutler, Ph.D.

Major Professor

Gary Moran, Ph.D.

Ronald Fisher, Ph.D.

Paul Foos, Ph. E.

Barry Crown, Ph.D.

Peter Craumer, Ph.D.

Date of Examination: July 31, 1990 


\section{ACKNOWLEDGEMENTS}

I wish to thank Jeff "the cat." And me. 
TABLE OF CONTENTS

Page

LIST OF TABLES

vii

LIST OF FIGURES

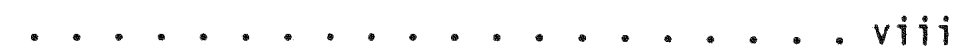

INTRODUCTION

The Right to a Trial by Fair Jurors .......... 1

Threats to Sixth Amendment Rights ......... 1

Jurors may not understand the law ....... 3

Prejudice arising from personal

traits or direct experience ....... 5

Cognitive mechanisms that mediate

prejudice ............ . . 6

The "story-model" as a rational

explanation .............. 8

Pretrial publicity may jeopardize

objectivity ..................... 11

How pretrial publicity mediates prejudice....... 12

Studies of the Effects of Pretrial Publicity

and Legal Safeguards ............. 15

Shortcomings of Voir Dire: The Most Popular Safeguard

Cognitive and social psychology

principles in voir dire ......... 23

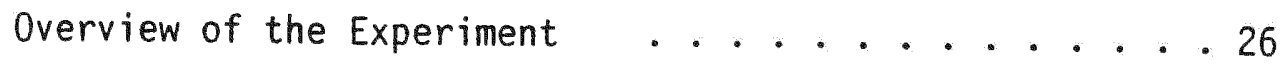

Brief description of the design and

procedure ..............26 
The problem of experimental realism . . . . 28 Predictions . . . . . . . . . . 28

METHOD

Experimental Design .................. 29

Subject Recruitment .............. 29

Characteristics of the sample ....... 30 Procedures ..................... 30

Preliminaries ..................... 30

Voir dire .......................... 30

Trial viewing ...................... 31

Jury deliberation ...................... 31

Stimulus Materials ..................... 31

Case-specific pretrial publicity ...... . 31

General interest news ......... 32

The Trial . . . . . . . . . . . 32

Independent Variables .................. 34

Voir dire ......................... 34

Judge-federal ................ 34

Attorney-extended ............. 35

Preliminary Assessments ............... 37

Pretrial prejudice ................ 37

Rehearsal of pretrial publicity ....... 37 
Dependent Measures ............. 38

Predeliberation survey .......... 38

Postdeliberation survey ......... 38

RESULTS

Descriptive Statistics ............... 39

Predeliberation verdict ................. 39

Predeliberation Effects ................ 40

Postdeliberation Effects ................ 41

DISCUSSION

Major Findings ...................... 43

The remedial effect of deliberation on prejudice created by media ........ 44

Problems with dichotomous variables ...... . 44

Does voir dire neutralize expectancy confirmation ........... 4 47

Policy Implications ................... 49

Comparisons between judge-minimal and attorney-extended voir dire ...... . . 49

Proposed legislative changes in voir dire ................. 51

Bermant's argument ......... 52

Statements made by the proponents of change 
Statements made by the opponents of change

Suggestions for Further Research ..........60 60

TABLES

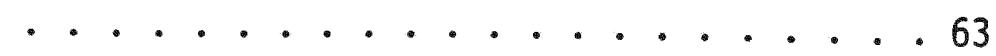

FIGURES

................... 64

APPENDICES

A: Demographics and Juror Bias Scale ....... . 66

B: Pre- and Postdeliberation Scales . . . . . 72

C: Case-Specific Pretrial Publicity ....... 75

D: Judge-Federal Voir Dire ........... 87

REFERENCES

VITA 


\section{LIST OF TABLES}

Table 1 Descriptive Statistics

Table 2 Predeliberation Verdict

Table 3 Postdeliberation Verdict 


\section{LIST OF FIGURES}

Figure 1 Predeliberation Verdicts

Figure 2 Postdeliberation Verdicts 
I. Introduction

\section{A. The Right to a Trial by Fair Jurors}

In a time when society is motivated to crack down on crime, it is possible to lose sight of the accused's constitutional rights. The Sixth Amendment to the United States Constitution guarantees all criminal defendants the right to trial by a fair and impartial jury meaning that, when asked by the judge or lawyer if she can set aside prejudgments and render a verdict based on case evidence and the law, the seated juror will answer "yes" and mean it. "Fairness," by law, means that the juror, in presuming innocence, will force the state to prove a defendant's guilt beyond a reasonable doubt before convicting. Fairness means that jurors must base their verdicts only on the facts of the case at bar and on the law. But do ordinary people understand legal concepts such as presumption of innocence, burden of proof, and reasonable doubt well enough to agree to fairly apply them? Confusion about legal concepts is just a part of the problem; juror prejudice (whatever the source), insofar as it impairs objectivity, also poses a threat to due process.

In the context of this study, the issue of due process becomes important. What exactly constitutes justice? In an adversarial system, the opponents (i.e., trial lawyers) are expected to do their very best to protect the interests of their respective clients. To the degree that trial advocates pursue all lines of inquiry--leaving no 
stone unturned--one can say that justice is being served. In doing their jobs, trial adversaries must maximize the likelihood that their respective clients will emerge victorious. This author maintains that justice cannot be defined in terms of outcome (i.e., correct verdict) because, in an absolute sense, the correct verdict (i.e., did the defendant do the deed or not) is unknowable. Justice, then, is defined in terms of procedure, not outcome.

It is believed that voir dire, a process which presumably disqualifies prejudiced jury panelists, protects a defendant's constitutional right to trial by a fair jury. While the Courts feel satisfied that voir dire--as it is routinely conducted--offers the accused adequate protection, others believe that its effectiveness could be improved. The Department of Justice and the National Association of Criminal Defense Lawyers (NACDL) disagree as to who--the judge or defense counsel, respectively--should control the voir dire examination. Under the current rules judges have complete discretion and usually prefer to conduct voir dire themselves. In 1983, legislation which sought to transfer control of voir dire in federal district court was introduced, by Senator Heflin of Alabama, but failed. Proponents of change still believe that the judge-conducted voir dire yields little probative information. Without candid disclosure, trial lawyers cannot protect their clients from the damaging effects of undetected bias. The present study tests voir dire as a remedy for juror prejudice. 


\section{B. Threats to Sixth Amendment Rights}

1. Jurors may not understand the law. Although these points of law are familiar to all American citizens, there is reason to believe that their respective meaning and lawful application are not clearly understood. In fact, a nationwide study revealed that many jurors did not even know that "Court" referred to the judge (Elwork, Sales, \& Alfini, 1982). More to the point, however, Strawn and Buchanan (1976) found that $50 \%$ of instructed Florida jurors believed that it was the defendant's burden to prove innocence in a criminal trial. Concern over misunderstood legal terminology, then, seems entirely appropriate given that numerous studies demonstrate that jurors misunderstand and misapply legal concepts at virtually every stage of the trial process (Buchanan, Pryor, Taylor, \& Strawn, 1978; Charrow \& Charrow, 1979; Kagehiro \& Stanton, 1985; Kassin, 1985; Kassin \& Wrightsman, 1980, 1981, 1985; Schmolesky, Cutler, \& Penrod, 1988; Thompson \& Schumann, 1987). For example, research done by Elwork et al. $(1977,1982)$ as well as Severance and Loftus $(1981,1982)$ shows that jurors are confused by the case law that they are to apply during deliberation. Specifically, jurors misunderstood definitions of "intent" and "reasonable doubt." Other evidence suggests that jurors misapply instructions that limit use of prior convictions in criminal cases (e. g., Doob \& Kirshenbaum, 1973) and in joined trials, judicial instructions have not been able to offset impressions of defendant 
criminality (e.g., Horowitz, Bordens, \& Feldman, 1980; Green \& Loftus, 1981; Tanford \& Penrod, 1982, 1984; Tanford, Penrod, \& Collins, 1985). Findings such as these point out that misunderstanding and/or misapplication of the law can threaten a defendant's constitutional right to trial by fair jurors.

There are still other common misperceptions. For example, people often think that a person charged with a crime must have done something wrong or they think that the State would not spend time and money to put on a trial were there not plenty of evidence to convict. That people generally hold these beliefs is not the problem that threatens a defendant's constitutional rights. Such beliefs, however, are a problem when they interfere with a juror's ability to hear trial evidence objectively. Inability or unwillingness to set aside prejudgments constitutes failure to presume innocence. Directly related to presumption of innocence is burden of proof, another point of law that is commonly misunderstood by ordinary people. Ordinarily, individuals suspected of wrongdoing are expected to defend their actions: failure to explain one's actions creates an impression of guilt. But proof of innocence is not required of criminal defendants-the burden of proof is the State's alone--no proof, no guilt. People fail to understand this distinction between everyday life and the courtroom, and failure to hold the state to its burden constitutes failure to presume innocence. 
Among the more familiar points of law, the concept of reasonable doubt is the most ambiguous of all. When asked to express the reasonable doubt standard in percentages, subjects' responses ranged anywhere from 50 to 100 percent (Kagehiro \& Stanton, 1985). Worse yet, Kagehiro and Stanton (1985) found that standard of proof--be it preponderance of evidence or reasonable doubt--made no significant differences in verdict preferences. Clearly, there is sufficient evidence to suggest that misunderstanding of the law constitutes at least one threat to a defendant's constitutional right to trial by an impartial jury.

\section{Prejudice arising from personal traits or}

direct experience. But there are other threats to a defendant's constitutional right to trial by a fair jury, factors--which may arise knowingly or unknowingly--that can impair a juror's ability to presume innocence. For example, jurors who are friends or relatives of the litigants may be incapable of objectivity. While some jurors may not be cause-eligible (i.e., challenges based on specific, provable prejudice which are unlimited but which must be approved by the judge), they may, nonetheless, be prejudiced and the number of allowed peremptory challenges (which are limited but do not require specific reason or justification) are insufficient to excuse them all. These prejudices may arise from personal traits such as legal authoritarianism (Boehm, 1968) or they may be negative attitudes arising from jurors' 
firsthand victim experiences, particularly when a juror's experience is related to the defendant's charged offense, that have been linked to conviction-proneness (Cutler, Narby, \& Moran, 1990; Moran \& Comfort, 1982).

3. Cognitive mechanisms that mediate prejudice. People bring prejudice into the courtroom from a number of sources; misunderstanding of the law, personal traits, and direct experience are just a few of the ways by which an individual's constitutional right to presumed innocence is threatened. One goal of this research is to look at how preconceptions influence subsequent information-processing. Many trial judges are satisfied that potential jurors who agree to be fair can be, but judges presume that people generally are aware of the subtle ways in which prejudice works and that they are willing to admit prejudice publicly. Presuming instead that jurors are not impartial information-processors, I turn to the literature with the following question: Do people, as "intuitive" scientists searching for truth, process trial evidence rationally and objectively (Kelley, 1967, 1973; Ross, 1977)? Or is human information-processing subject to motivated distortions and if it is how can it be offset (Festinger, 1957; Heider, 1958; Adams, 1965; Berkowitz \& Walster, 1976)?

A raging controversy among attribution theorists, pits rational against motivational explanations of human informationprocessing. During the Sixties "hot" internal states, e.g., attitude 
change motivated by need to reduce arousal, was the focus of cognitive dynamics but with the emergence of the computer analogy in the Seventies and the ensuing cognitive revolution, "hot" cognitive explanations were supplanted by "cool" information-processing explanations. Theories such as correspondent inferences (Jones \& Davis, 1965) and Kelley's (1967. 1973) covariation model of attribution are two of the more influential social cognitive theories which portray humans as naive empiricists whose only information-processing errors are systematic and rational (e.g., Ross, 1977; Tversky \& Kahneman, 1974). The goal of "social cognition," as this emergent field was called, is to explain human information-processing without invoking motivation. The question is which of the two positions is best supported by empirical research? We know from an extensive schema literature that preconceptions based on past experiences are tenacious, difficult to dislodge, and are thought to drive subsequent information-processing (e.g., Bruner \& Goodman, 1947; Bruner, 1973; Wyer, 1974, 1975a, 1976; Wyer \& Sru11, 1980). Among the earliest and most innovative cognitive psychologists, Bartlett (1932), even before Bruner's "new look in perception," portrayed humans as active information-processors. He postulated theories of learning and remembering that directly impact on trial settings. According to Bartlett, learning new material requires "effort after meaning"; that is, encoded memory does not duplicate reality rather people change new information to fit existing schemas. 
Furthermore, Bartlett claimed that remembering, as a reconstructive process, is not detailed but schematic. Because remembering is based on general impressions, people recall details that seem correct but may not be.

Lord, Ross, and Lepper (1979), in their classic study on expectancy confirmation, point out the shortcomings of laypersons as intuitive scientists. Hypothesizing that data relevant to a particular belief are not processed impartially, Lord et al. (1979) demonstrated that subjects on opposite sides of the capital punishment issue found support for their respective positions despite the fact that they were given the same relevant empirical evidence. Expectancy confirmation served to bolster subjects' original positions and polarize the opposing factions. On recall, subjects characterized the "confirming" evidence as highly reliable and the "disconfirming" evidence as unreliable. Because both groups were given the same data but reached polar opposite conclusions, these findings suggest that people impose their own world view on available information during decision making. That expectancies influence perception--particularly person perception--is not news (e.g., James, 1890; Snyder, Tanke, \& Berscheid, 1977; Snyder \& Swann, 1978a; Zadny \& Gerard, 1974; Taylor, Fiske, Etcoff, \& Ruderman, 1978). Clearly, these findings have implications for the constitutional issues at hand.

4. The "story-model" as a rational explanation. Other 
researchers ignore the effects of preconceptions on jury decisions. For example, Pennington and Hastie (1986) suggest that jurors construct a cohesive story from trial evidence and then match the "story" with the "best fitting" verdict category. According to Pennington et al. (1986) the story is the schema or mental representation that determines verdict choice. My reading of the schema literature suggests that causality moves instead from verdict to story construction, that one's impression (schema) of guilt or innocence influences not only jurors' encoding of trial testimony but also retrieval of case facts to support verdict choice.

Although the "story model" is supposed to explain juror behavior, it fails to address some important questions. For example, what is driving information-processing while jurors listen to testimony? It cannot be the story (i.e., the schema) because the story is not finished until the trial is over, according to Pennington and Hastie (1986). Do they mean to say that jurors do not consider the question of guilt or innocence until they have heard all testimony and are ready to deliberate? To support their argument Pennington et al. (1986) claim that subjects making different verdict choices constructed different stories. It is easy to understand how stories would be consistent with verdict choice and that the stories are different depending on verdict choice. But what produced the different stories in the first place? If it is true that verdict assignment is made after a plausible story has 
been constructed, then what contributes to differences in story construction? They all hear the same testimony, why then do people receiving identical information construct different stories? Lord, Ross, and Lepper (1979) and others (e.g., Bartlett, 1932; Bruner, 1973; Bruner \& Goodman, 1947) would suggest that preexisting hypotheses (e.g.. stereotypes, world view) drive the processing of trial testimony. Pennington and Hastie (1986) assessed story "cohesiveness" (i.e., does it hang together or contain the necessary components of episode schema). The problem with measuring cohesiveness is that most people, when asked to tell a story, will make it sound plausible because to do otherwise would reflect badly on them. It is possible that the story hangs together because subjects were instructed to tell a story and not because of any memory representation that is called up to help make verdict decisions. Story cohesiveness, then, may be an experimental artifact due to instructional set. The question, then, seems to be one of causal order. There is much evidence to suggest that prospective jurors come into the trial situation with a verdict preference, or at least inclination, either based on preconceptions about how certain classes of people behave (e.g., Taylor, 1982; Hastie, 1980; Wyer \& Sru11, 1980; Snyder \& Uranowitz, 1978) or prejudgments resulting from exposure to pretrial information (e.g., pretrial publicity; Carrol1, Kerr, Alfini, Weaver, MacCoun \& Feldman, 1986; Moran \& Cutler, in press) and construct the story (i.e., select evidence) that 
supports their predetermined preference (Lord et al. 1979).

5. Pretrial publicity may jeopardize objectivity. Recently the controversy over free press versus fair trial has created a stir. As yet another factor that has been found to jeopardize juror objectivity, pretrial publicity may threaten a defendant's constitutional right to a fair trial. But before examining whether or not exposure to pretrial publicity prejudices jurors against a defendant, it should be pointed out that there are interpretational problems associated with the concept of juror prejudice that may bear on resolution of the ongoing debate. The issue is two-fold including problems with definition and practical application.

On the one hand, social scientists attempting to demonstrate the biasing effects of prejudicial pretrial publicity, define prejudice as a state of mind that differentially inclines one toward a particular litigant (Moran \& Cutler, in press). The courts, rejecting generic definitions of prejudice, claim that social science findings reveal an "inadequate understanding of the way pretrial publicity influences the thought processes of prospective jurors" (American Bar Association, $1978, p .20)$. The problem centers on the law's disinterest in defining prejudice in general terms, concentrating instead on prejudice as it idiosyncratically bears on specific cases. From a legal perspective, then, prejudice must be defined contextually and cannot, as social scientists typically do, be operationally defined for use in standard 
methodologies.

Complicating the issue even further, the law circularly defines prejudice as the inability to serve as a fair and impartial juror. "Impartiality," however, is not a technical term it is a state of mind, and as such requires operational definition before its existence can be determined. Unfortunately, there are no hard and fast rules to determine whether or not prejudice exists (Irvin v. Dowd, 1961). The Supreme Court does, however, specify that neither knowledge, abhorrence, nor perceived notions regarding a defendant's actions constitute prejudice; rather, prejudice must be an ongoing phenomenon. In the legal sense, prejudice has been defined as a "fixed" opinion held by the prospective juror that, given the circumstances surrounding a particular case, cannot be changed (Murphy v. Florida, 1975).

\section{A. How Pretrial Publicity Mediates Prejudice}

How exactly does pretrial publicity create prejudice in either the social science or the jurisprudential sense? First of all, the media are not held to very high standards. For example what they report (newspaper as well as TV coverage) does not have to be accurate which is why there is an open editorial policy. Details reported by the media are not evidence. News stories are designed to get attention and to do so they are often exaggerated, inflammatory, and sensational; news is designed that way to create a certain impression and because it sells newspapers. Unfortunately, once that impression has been created it is difficult to remember that it is not based on the facts. 
Secondly, often what is reported in the media is information that ordinarily would not be admitted in the courtroom, information such as a defendant's prior criminal record or general misbehavior. The reason this kind of information is not admitted in the courtroom is because of its prejudicial effect and that is why officers of the law, both judges and attorneys, ask prospective jurors if they have read or heard about the case. For example, knowing that the defendant has a prior arrest or conviction record gives the impression of criminality and it is this impression that interferes with the ability to limit judgment to the case facts. But just as it is unconstitutional to deny any defendant the right to trial by a fair and impartial jury it is, likewise, unconstitutional to deny freedom of the press. In the interest of justice, one goal of voir dire should be to make jurors aware of how pretrial publicity creates prejudice so that they, because they want to be fair, will recognize prejudice in themselves and either choose to excuse themselves or put prejudgment aside.

Pretrial publicity mediates prejudice in yet other ways. For example, surveys conducted by Moran and Cutler (in press) and by Costantini and King (1980/1981) found that knowledge of pretrial publicity is significantly correlated with perceived defendant culpability; that is, people who remember publicity details (most pretrial publicity is biased against the defendant) are more likely to believe that there is a lot of evidence against the defendant. Pretrial 
publicity statements are made most often by prosecutors and law enforcement agents, credible professionals whose word often goes unchallenged. Other evidence suggests that publicity of an emotional nature is more prejudicial than publicity that is factual (Taylor \& Fiske, 1978; Nisbett, Borgida, Crandal1, \& Reed, 1976) and that people tend to remember information that supports their theory about how certain classes of people behave (Neisser, 1976; Snyder \& Uranowitz, 1978; Taylor, 1982; Taylor \& Crocker, 1980).

People are more likely to remember news details that are schema-consistent, and we know that information availability affects later judgments (Tversky \& Kahneman, 1973, 1974). In a drug trial, then, media facts that support a personal theory about drug users are recalled best and not only strengthen one's theory about drug users but also affect one's ability to evaluate the trial evidence objectively. But reinforcing or strengthening an already existing theory about certain categories of people is not the only way that pretrial publicity affects objectivity. Where prejudice against members of certain classes does not already exist, pretrial publicity, because it is vivid, inflammatory, and sensational, can create negative impressions that jurors would not otherwise have (Nisbett, et al., 1976; Taylor \& Fiske, 1978); the biasing process is subtle and most people are unaware of its effects (e.g., Neisser, 1976; Nisbett \& Wi1son, 1977). 


\section{Studies of the Effects of Pretrial Publicity and}

\section{Legal Safeguards}

News covering the details of the crime, the charge, the defendant's prior criminal record, as well as attorneys' and witnesses comments may affect jurors' attitudes toward the defendant, particularly when the publicity is inflammatory. In criminal cases, prejudice (of which jurors are often unaware), may contaminate juror informationprocessing making fairness and impartiality virtually impossible. Actual Supreme Court cases (e.g., Irvin v. Dowd, 1961; Rideau V. Louisiana, 1963; Sheppard V. Maxwell, 1966) illustrate this contention.

A review of empirical simulation techniques, however, leaves many questions unanswered. It is worth mentioning that after two decades of research, the fewer than a dozen studies addressing these issues yield little usable knowledge (Carroll et al., 1986). To simplify this discussion, I have organized the relevant research findings according to their respective methodologies beginning with surveys of community opinion. Although a number of survey studies show that impressions created by pretrial publicity influence perceptions of defendant culpability, none have demonstrated that pretrial publicity directly influences juror verdicts (e.g., Moran \& Cutler, in press; Costantini \& King, 1980/1981). Several studies assessed the effects of pretrial publicity on perceptions of guilt where subjects received no case facts other than those contained in news accounts. Various 
categories of pretrial publicity, that are presumed by the American Bar Association to produce prejudice in the average news consumer, were found to create a prejudicial attitude. Reports of a defendant's confession (DeLuca, 1979; Tans \& Chaffee, 1966; Wilcox \& McCombs, 1967), prior record (DeLuca, 1979; Hvistendah1, 1979), and failed polygraph (DeLuca, 1979) were found to increase guilty ratings but, because no case facts were presented beyond the news articles themselves, these impressions of guilt cannot be generalized to juror verdicts.

More interesting are studies that examined media impact on jury verdicts by exposing subjects to pretrial news and then showing trial transcripts or videotaped trial reenactment. Typically tested, along with the effects of pretrial publicity, are one or the other popular safeguards used by the court to offset its prejudicial impact. One pioneering study that examined the impact of pretrial publicity on juror verdicts concluded that judicial admonitions cured the potential adverse effects created by either factual or sensational newspaper clippings about a murder case (Simon, 1966). The study, however, suffered methodologically (e.g., the State's case was especially weak and the design lacked conditions without judicial admonitions). Other simulated jury studies, where juror verdicts are elicited, do yield effects for news exposure that are not remedied by judicial admonitions (e.g., Padawer-Singer \& Barton, 1975; Sue, Smith \& Gilbert, 1974; Kline \& Jess, 1966; Tans \& Chaffee, 1966). For example, subjects in the Sue, 
Smith, and Gilbert (1974) study read newspaper accounts claiming that a gun found in the defendant's room either was or was not the murder weapon, information which, in either case, is inadmissable due to an illegal search. Subjects were either admonished or not by the court to disregard what they had read. After reading a one-page summary of the case, subjects gave verdicts and rated the strength of the cases for the prosecution and for the defense. Unlike Simon's (1966) findings, Sue et al. (1974) found that subjects' verdicts were influenced by the news coverage and that judicial admonitions failed to offset its effects. This is not surprising since the amount of information contained in a one-page case sumnary was insufficient to compete with sensationalized news stories.

Neither did jury deliberation attenuate the effects of prejudicial news coverage. For example, Kline and Jess (1966), found that, despite judicial admonitions, their four juries referred to prejudicial news reports during deliberation and that one jury actually based its verdict partly on the media coverage. Zanzola (1977) also found deliberation effects for news stories despite the fact that media bias was not reflected in predeliberation verdicts. Although news coverage of the defendant was of a positive nature, it shows, nonetheless, that deliberation can exaggerate rather than diminish the effects of pretrial publicity.

Besides judicial admonitions and jury deliberation, attempts 
to offset the untoward effects of pretrial publicity with voir dire--the remedy in which judges most strongly believe--have also failed. Sue, Smith and Pedroza (1975) found that subjects who disclosed personal prejudice were more likely to convict than those who did not but that the effect remained among those who claimed impartiality. PadawerSinger, Singer, and Singer (1974) found differences among subjects who were voir dired versus those who did not undergo the voir dire examination for prejudice. Surprisingly, voir dire, which was supposed to decrease convictions among subjects exposed to prejudicial media accounts, instead increased the number of convictions among subjects who read neutral news stories.

What can be made, then, of the extant empirical research on the effects of pretrial publicity on juror judgments? 0tto, Penrod, and Hirt (1990) claim that the current research disallows conclusive answers to questions about when and how news coverage affects the defendant's right to a fair trial. And based on their review of the literature on the effects of pretrial publicity, Carroll et al. (1986) conclude that "our understanding of the effects of news coverage is still fragmentary...there is evidence that [pretrial publicity] effects can carry through a trial to jury verdict, but there is very little evidence regarding the effectiveness of various remedies applied by the court." Although there continues to be substantial interest among legal psychologists in the particular prejudicial effects of pretrial 
publicity on juror judgments, it is misleading to market this research (and it often is) as the "free press/fair trial" controversy--it is not as though we can choose between them--because free press is a permanent feature of democracy. Calling the problem free press versus fair trial is to misstate it. The real problem concerns the issue of constitutional rights, that is, a defendant's right to be presumed innocent until and unless the state meets its burden of proof. Because pretrial publicity tends to exacerbate or even create prejudice where it did not exist, it makes a good vehicle for determining what, if any, influence prejudgments have on verdicts as well as for comparing the remedial effectiveness of different voir dire formats.

While the courts concede that pretrial publicity may prejudice prospective jurors against criminal defendants, they are confident that legal safeguards, namely change of venue, judicial admonitions, and voir dire, are effective remedies. Moving the trial, for one, is undesirable because it is (a) inconvenient and (b) at odds with the constitutional provision that a case be tried in accordance with the standards of the community in which the crime was committed. Concern over whether change of venue is a corrective for pretrial publicity prejudice has been expressed for yet another reason. While pretrial publicity can exacerbate preexisting prejudice it is not known when pretrial publicity is the original source, and that moving the trial cannot guarantee that the alternative community will be prejudice- 
free (Carroll et a1., 1986). Public opinion surveys used for changes of venue seek to establish a link between exposure to pretrial publicity and prejudgment about a case (e.g., Nietzel \& Dillehay, 1986; Vidmar \& Judson, 1981). But, as Carroll et al. note (1986), it is difficult to know whether the differences observed are due to news coverage or preexisting attitudes correlated with selective reading by media consumers. The present research addressed this question. In sum it is interesting to note, that despite the cost and inconvenience to the courts, legal psychologists continue to involve themselves in venue change issues rather than exploring ways to remedy prejudice through improved use of voir dire.

E. Shortcomings of Voir Dire: The Most Popular Safeguard Clearly, voir dire is the most popular of the court's safeguards against prejudice. The trial judge decides who will conduct the voir dire examination and how extensive it will be. In terms of disclosing juror prejudice, there are problems with both the federal (judge-conducted) and state (attorney-conducted) models. Each will be discussed in turn beginning with attorney-conducted models.

There are two approaches or goals of attorney-conducted voir dire and ultimately its effectiveness may depend on how it is used. Typically, voir dire is used as a jury selection procedure. The goal here is simple: identify and excuse individuals who, wittingly or unwittingly, reveal prejudice. There is, however, reason to doubt the 
efficacy of voir dire if used as a selection procedure. The point is that attorneys are given a limited number of peremptory challenges per trial. Given that some degree of prejudice is natural and therefore pervasive it is illogical to think that voir dire will eliminate it all. This is true as long as the number of prejudiced venirepersons outnumbers available peremptory challenges. Concentrating exclusively on improving jury "selection" methods is $i l 1$ advised because the result (using simple mathematics) will still be a prejudiced jury.

There is another reason to suspect that jury selection does not eliminate pretrial publicity prejudice. During the selection process, attorneys typically question some subgroup of the larger jury panel. Even if the attorney selects with perfect accuracy people who are prejudiced, once an attorney's peremptories have been used up she or he has to take whomever is next in line--possibly people who are at least as prejudiced as those excused.

Trial attorneys, however, are not always allowed to conduct the voir dire examination and, despite its shortcomings when used as a selection procedure, it may, nevertheless, do better at producing an impartial jury than its alternative, the judge-conducted voir dire. When designed properly, questions put to jurors during voir dire can reveal personal attitudes on any given topic. However, when the wrong questions are asked or if jurors feel pressured, disclosures of prejudice may be suppressed $\left(0^{\prime}\right.$ Conne 11,1988$)$. If the fairness of jury 
selection depends on the nature and the extent of questioning during voir dire, then Hennenberg and DeVan (1987) ask:

What does a judge expect when she asks a prospective juror if he has any broad-based bias or prejudice? Do judges really think that an individual will answer, 'Yes, I feel all Columbians charged with cocaine conspiracy are probably guilty?' (p. 20).

It is doubtful that people will be so candid especially when the socially desirable response shifts the attention from oneself to someone else. Typically, the last question the trial judge asks is whether the juror can render a fair and impartial verdict and if answered in the affirmative the juror qualifies to sit on the jury (Irvin v. Dowd, 1961). Practices such as these directly bear on the present study and are summarized best by 0'Connell (1988):

This methodology is a little like asking a practicing alcoholic if he has his drinking under control; we are asking the person who has the prejudice to determine if the prejudice will affect his decision (p. 183).

Unfortunately, this type of voir dire format--where jurors are unlikely to expose prejudice--has been approved by the Supreme Court. To-date, no better method has been developed (0'Connel1, 1988).

Believing still that voir dire can be the most effective among traditional judicial remedies, Penrod and Linz (1984) suggest some 
alternative goals. They recommend that attorneys use voir dire to: explain and emphasize points of law making them available during deliberation; build rapport; and solicit public commitments from jurors. For purposes of the present study, these suggestions form the core around which the attorney-extended voir dire was patterned. In addition, questions as to the effects of prejudicial pretrial publicity need to be answered. By showing that incriminating news stories impede juror objectivity and by testing different strategies for voir dire--the favorite of judicial remedies--the present study attempts to provide some answers to these pressing, contemporary questions.

1. Cognitive and social psychology principles in voir dire. The better approach to voir dire, then, is education rather than elimination. If complete elimination of prejudice is impossible (not enough peremptories to excuse all prejudiced jurors) then attorneys must instead use voir dire to help jurors behave in accordance with the law. Rather than attempting to weed out prejudice, the goal of voir dire becomes committing the jury to uphold the law. Individuals who come into the courtroom with preexisting prejudice (whatever its source) can be persuaded, using cognitive and social psychological principles such as availability, commitment and accountability, to suspend judgment.

Penrod and Linz (1984) suggest a number of ways to improve the current use of voir dire. As already discussed, there is 
considerable evidence to suggest that jurors misunderstand and misapply the law. In addition to concentrating on removing biased jurors, trial attorneys might put voir dire to better use by first explaining relevant legal concepts. Confused jurors could be made to understand what specific points of law mean and how to apply them lawfully. From a cognitive perspective, lawful meanings and applications would then be available during deliberation where before confusion existed (Tversky \& Kahneman, 1974).

Research done by Snyder (1982) suggests that, if integrated, cognitive and social psychological principles can bear directly on juror decisionmaking. For example, in the area of attitude-behavior consistency, findings suggest that attitudes that are both "available" and "relevant" are more likely translated into action (Snyder, 1982). Be it an attitude about a specific class of people or understanding of relevant legalities, when asked during voir dire, the average juror may not have answers readily available. For many individuals, this may be the first time they have been asked to consider feelings about someone who has previously been convicted of a criminal offense or the concept of reasonable doubt to name but two legal concepts that might be introduced during a criminal trial. By drawing out commonly held misconceptions and by soliciting public commitments to fairly apply the law as they now understand it, attorneys can facilitate impartiality during juror decisionmaking. Snyder's (1982) findings suggest that 
correspondence between correct understanding of legal concepts and their lawful application during deliberation is more likely when jurors are asked to carefully consider and then agree to apply appropriate laws during decisionmaking.

From an extensive literature on persuasion and attitude change we know that individuals experience discomfort when they perceive inconsistency between their attitudes and behavior (Festinger, 1957). This need to see oneself as consistent motivates people to follow through on behaviors that they publicly commit to (Kiesler, 1971). In fact, persons who make public commitments to one side or another of a particular issue are less likely to be persuaded later on by countermessages (Kiesler \& Sakumura, 1966). Public commitment can also determine whether or not forewarning influences attitude change. For example, Kiesler (1971) found that subjects, who did not publicly express their position and who were told to expect that others would attempt to change their minds, abandoned their original beliefs in anticipation of the forewarned attack. In contrast, subjects from whom public commitments were solicited became more extreme in their original positions when forewarned. The potential for social psychology to address matters of constitutional right is summarized best by Snyder (1982) who notes:

If there is one message that comes through loud and clear from generations of research in social psychology, that 
message is the power of situational forces to influence social behavior. Peer group pressures, reference group norms, role requirements, incentives and sanctions may singly and together appear to be impossible to ignore ( $p$. 114) .

Fashioning a voir dire that utilizes cognitive and social psychological principles is the primary goal of the present research.

F. Overview of the Experiment

1. Brief description of the design and procedure. The present study was designed to compare an extended voir dire with the federal model for its ability to reduce prejudice in general and/or prejudice associated with pretrial publicity. As Carroll et al., (1986) note, the effectiveness of traditional jury selection as a remedy for pretrial publicity rests on at least two assumptions. The first is that jurors have cognitive access to the source of prejudice--be it pretrial publicity or past experiences--and the other is that prospective jurors are willing to report prejudice in any of its forms. That defense attorneys feel frustrated when the Court asks jury panelists whether they can be fair and jurors perfunctorily reply, "Sure, I think I can be," is a restatement of the problem only expressed from the legal perspective (Hennenberg \& DeVan, 1987).

In the only study of its kind, Jones (1987) found that the source of voir dire (judge or attorney) and delivery style (formal or 
casual) has differential impact on juror disclosure. Measuring discrepancies between pretested juror attitudes (questionnaire) and attitudes expressed publicly during voir, Jones demonstrated that jurors change their responses almost twice as much before a judge than before an attorney. These results support the contention that potential jurors disclose more candidly with attorneys probably because a judge's status pressures them toward compliance to a set of perceived judicial standards.

With this in mind, I tested the efficacy of an extended voir dire strategy--where attorneys seek to educate rather than eliminate prejudice--against the minimalist judge-federal model. Using a fourfold (henceforth to be called "attorney-extended") format I intend to: (a) provide "insights" as to the prejudicial effects of pretrial publicity; (b) call jurors' attention to the relevant points of law and explain what is meant by them; (c) elicit individual and public commitments to comply with the law; and (d) make jurors accountable (to each other) for their actions. I predicted that combining insight, public commitment, and juror accountability will (a) focus jurors' attention on the evidence and (b) convince jurors to keep the burden of proof on the government. This should (c) ensure that jurors hold the government to its burden of proving guilt beyond a reasonable doubt and should be manifested in a reduced conviction-rate. 


\section{The problem of experimental realism. Legal}

psychologists know how difficult it is to effect policy change in the legal system. On a number of issues, social science findings have been offered to the courts (e.g., death qualification) but have been rejected on the grounds that empirical studies do not approximate the real world. Clearly, our research goals and methods must appeal to the legal system before they will take proper notice. For this reason attempting to improve voir dire, which is the most popular legal remedy for prejudice, seemed the most productive research choice. As Carroll et al. (1986) point out, research using realistic cases, publicity, and involved parties or shadow juries--methodologies that could enhance experimental realism--are inconvenient, time-consuming, and expensive. Voir dire conducted by practicing local attorneys in a realistic courtroom setting, as a first-of-its-kind methodology, seemed like a reasonable compromise. Finally, it is important to say, that our goal is not simply to identify problems inherent in the legal system but to work within it and improve what, with all its faults, is an essentially sound institution.

3. Predictions. Based on cognitive and social psychological theory as well as on empirical findings reported in the psycholegal literature, I predict (A) a main effect for pretrial publicity such that subjects exposed to PTP will convict significantly more often than subjects not exposed. As for voir dire, several 
possibilities are entertained. If $(B)$ voir dire reduces only general bias (and not specific bias such as PTP), I should observe an unqualified main effect for voir dire such that subjects in the attorney-extended condition convict less often than subjects in the judge-federal voir dire. If (C) voir dire reduces only specific bias, then I should observe no main effect for voir dire but an interaction showing that the simple main effect for PTP is significantly smaller among subjects in the attorney-extended condition as compared with subjects in the judge-federal voir dire condition. If (D) voir dire reduces both general and specific biases, then I should observe both the main effect (B) and the interaction with PTP (C). If voir dire reduces neither bias, the main effect (B) and interaction (C) would be nonsignificant.

II. Method

\section{A. Experimental Design}

The design is a fully-crossed two-way factorial where factors are (a) voir dire (judge-federal, attorney-extended) and (b) pretrial publicity (case-specific pretrial publicity, NO pretrial publicity). Subjects in the No pretrial publicity conditions read general interest news stories.

\section{B. Subject Recruitment}

Sixty eight subjects were recruited from a variety of courses, e.g., introductory psychology, legal psychology, developmental 
psychology, memory and cognition and were given extra credit for their participation.

1. Characteristics of the sample. The demographics

breakdown of the sample is as follows: Sex: male $=28 \%$; female $=72 \%$; Age: $17-29=74 \% ; \quad 30-39=13 \% ; \quad 40-49=1 \% ;$ Race: white $=54 \% ;$ black $=13 \%$;

hispanic $=28 \%$; other $=4 \% ;$ Marital status: never married $=69 \%$; divorced ( single) $=12 \%$; married $=19 \%$; Number of Children: $0=77 \% ; 1=16 \% ; 2=6 \% ; 3=1 \%$; Prior Jury Service: criminal jury $=7 \%$; civil jury $=6 \%$.

\section{Procedures}

1. Preliminaries. The week prior to the actual proceedings, demographic and the Juror Bias Scale surveys were administered in those psychology classes included in the sample. Following completion of the questionnaires, news packets were distributed. This was done in class to insure that subjects would read and, for those receiving pretrial publicity, rehearse the newspaper information.

2. Voir dire. All proceedings took place at the University of Miami law school. Voir dire, trial viewing, and deliberations were conducted in U-M's moot courtroom. Subjects were randomly assigned to one of the two voir dire conditions. Successive voir dire examinations were conducted in the courtroom by the same legal ensemble (i.e., judge, prosecutor, defense attorney) beginning with the judge-federal voir dire. During voir dire, and afterward, subjects (whose turn was either 
over or not up yet) waited in a common area. Subjects in the attorneyextended condition waited fifteen minutes while subjects went through voir dire by the judge. Attorneys admonished subjects not to discuss anything relevant to the trial.

3. Trial viewing. After both groups had gone through voir dire, subjects were reassembled in the courtroom to view the videotaped trial. Four 19-inch TV monitors, strategically positioned for easy viewing, were used to show the trial. At the trial's end, subjects were assigned to juries and moved to deliberation rooms.

4. Jury deliberation. Just before deliberation, subjects completed the predeliberation survey. This was done independently rather than as a group. When done, subjects deliberated for one hour or until they reached a unanimous decision. All deliberations were recorded on audiotape. After deliberation, subjects completed the postdeliberation survey and were debriefed.

\section{Stimulus Materials}

1. Case-specific pretrial publicity. All media packets contained seven news accounts of the murder case on which our stimulus trial is based. Articles were from the front page (including headlines) and from elsewhere in the newspaper. The articles were shuffled within each packet to avoid clustering of specific types of information. Subjects within a condition received identical news packets. Included in the publicity packet were seven fictionalized news articles all built 
on the original media coverage of the stimulus case, a Milwaukee, Wisconsin murder. Starting with the basic case facts, statements about the defendant's prior criminal record, character, retracted confession, drug use, and physical abusiveness have been added to each article, information that the ABA has called "highly prejudicial." Dexter, Penrod, and Linz (1988) found that excessive negativity in a news story reduced its prejudicial effect so care was taken not to overdo the inflammatory tone of each article. All the "fictionalized" articles have the appearance of typical news stories in style, language, and format.

2. General interest news. Subjects received a publicity packet that contained 10 local interest-type, noncrime-related news stories. These are originals that were not modified.

3. The Trial. The original trial was a six hour videotaped mock trial based on an actual criminal case from the State Bar of Wisconsin (i.e., Trial of a Criminal Case, 1982). The state charged the defendant with first degree murder, contending that the victim was murdered after he made a pass at the defendant's girlfriend and that there may have been some involvement with drugs. Witnesses testified that the defendant had been holding the gun at the time of the shooting. The Defense, on the other hand, claimed that there were no eyewitnesses to the actual shooting. Also, a forensic expert testified that the bullet traveled at a 45 degree angle through the head of the deceased 
and would have to have been fired by a person positioned right next to him. Witnesses, however, testified that the defendant had been standing 8 to 10 feet away from the deceased when the shot was fired.

The videotape was filmed in an actual courtroom from a juror's perspective. Playing the roles of judge, prosecutor, and defense counsel in the videotaped reenactment are the individuals who actually tried the case. The witness roles are played by actors. The videotaped reenactment followed the actual trial format beginning with the prosecution and defense opening statements; direct- and crossexamination of four witnesses; prosecution and defense closing arguments; and standard instructions from the judge. The reenactment is well done and compelling. Because jury simulation studies have been criticized justifiably on the grounds that they lack experimental realism, we did an exhaustive search for just the right trial. In an effort to avoid ceiling effects for defendant guilt some of the more incriminating testimony was edited out. The trial testimony ideally should be balanced to allow equally for either guilty and not guilty verdicts; evidence that is even-handed or ambiguous creates an opportunity for juror judgments to be influenced by personal prejudice. Pretesting showed this to be the case, $\mathrm{n}=10$; Guilty $=60 \%$; Not Guilty $=40 \%$. It should be noted also that the real jury in this case deadlocked. 


\section{E. Independent Variables}

1. Voir dire. Two different voir dire formats were used. The "judge-federal" voir dire is a bare-bones type of examination typically used in the federal courts. It relies on perfunctory questions (usually there is only one socially desirable response) requiring only a "yes" or "no" response (Jurywork, 1979). In contrast, the "attorney-extended" voir dire allows attorneys considerable latitude. Seasoned local attorneys play the roles of prosecutor and defense counsel in both voir dire conditions.

\section{a. Judge-federal. The standard voir dire} examination, consisting of approximately 10 general questions, was conducted by the judge (federal model). These questions, which when put to the jury are supposed to probe the jury panel for prejudice, tend to be superficial and give little opportunity for those queried to disclose anything at all. Questions like:

Is there anyone on this jury panel who cannot, or will not, try this case fairly and impartially, based solely on the evidence that is received here in court, and under the instructions on the law as given to you by the court, and render a just and true verdict?

is the kind typically asked by the judge and often by attorneys during voir dire. Most standard voir dire questions are asked to ascertain whether members of the jury panel know any of the trial principals 
(e.g., attorneys, defendant, victim, witnesses, law enforcement officers, experts, etc.) or have any personal interest in the case at bar (for a transcript of the judge-federal voir dire please refer to Appendix D) .

b. Attorney-extended. Before putting questions directly to prospective jurors, attorneys conducting the "attorneyextended" voir dire offered insights as to (a) the nature of prejudice, e.g., as a result of personal experiences, stereotyping, pretrial publicity; as well as (b) commonly misunderstood points of law, e.g., burden of proof, presumption of innocence, and standards of proof. In so doing, correct application of these points of law were made available for use during juror decision making.

It has been argued in the psycholegal literature that voir dire does not effectively weed out prejudice because prospective jurors, like most people, are unaware of its existence in themselves (Carroll et al., 1986). Defense counsel used voir dire first as an opportunity to explain how prejudice works and the questions themselves, when put to the jury panel, elicited from them commitments to set aside prejudice. Rather than condemning prejudice, which makes its disclosure highly unlikely, defense counsel took a different tack. He began by insisting that we are all prejudiced--that it is essentially human--and in the interest of justice we must try to recognize prejudice in ourselves so that we may set it aside. Public commitment and accountability-- 
reliable social phenomena--served to guide me in this process. Based on empirical findings we expected that the juror who publicly pledges to suspend judgment and who would have to justify her or his verdict decision during deliberation is likely to uphold that commitment (Tetlock, 1983). We know also that people are motivated to reduce inconsistency between their attitudes and behavior (Festinger, 1957). With this approach the goal of voir dire shifts from elimination (for prejudice) to education (from prejudice) and is a process that reinforces rather than punishes honest disclosure.

Contrasts between the judge-federal and attorney-extended voir dire conditions were sharply defined in terms of length, content, and rapport. For example, the judge-federal voir dire was brief (only fifteen minutes long), the questions were more like statements to which jurors would perfunctorily respond, and no attempt was made by the judge to establish rapport between himself and individual jurors. In contrast, the attorney-extended voir dire was an hour long during which time defense counsel provided insights on commonly misunderstood points of law. By engaging in a question/response dialogue with individuals jurors, defense counsel not only established rapport but supplied clarifications on crucial points of law where confusions previously existed. Most importantly, defense counsel elicited public commitments to objectivity from a number of juror/subjects. The prosecutor, in the attorney-extended voir dire, played a non-role in the sense that her 
questioning (three questions) was patterned after the perfunctory judgestyle only briefer.

\section{F. Preliminary Assessments}

1. Pretrial prejudice. Prior to viewing the videotaped trial, subjects completed the Juror Bias Scale developed by Kassin and Wrightsman (1983). These data gave me some idea of my subjects' prejudices before they were subjected to experimental manipulations. Kassin and Wrightsman (1983) found that the instrument (a) reliably predicted individual differences, i.e., legal authoritarianism versus civil libertarianism; (b) was not influenced by social desirability factors; and, for our purposes, (c) allows for assessment of randomization effectiveness. Questions such as "If a suspect runs from the police, then he probably committed the crime;" "Out of every 100 people brought to trial, at least 75 are guilty of the crime with which they are charged;" and "Too many innocent people are wrongfully imprisoned" were among those included.

2. Rehearsal of pretrial publicity. Before viewing the stimulus trial, subjects received a publicity packet. Materials were distributed and read in class after which subjects reported, in openended format, (a) if they had an opinion as to the guilt or innocence of each murder defendant and (b) what evidence could they cite to support their opinion. Forcing immediate rehearsal of the inflammatory and incriminating publicity details was an attempt to maximize its 
prejudicial effects.

\section{G. Dependent Measures}

1. Predeliberation survey. At the trial's end but before deliberation began subjects were asked (again, in open-ended format) to state, in story form, their verdict preference and all supporting evidence. Subjects also gave us verdict confidence ratings. To measure the impact of witness testimony on jury decision making, subjects were asked to rate, on 9-point Likert rating scales, (a) credibility of each witness and (b) strength of prosection's and defense's case. It was important to determine whether or not there were any voir dire effects (i.e., education) before deliberation where any voir dire effects could be masked by the effects of social influence. This constitutes the second attitude assessment--an opportunity to determine whether or not preexisting attitudes (schemas) prevail or can be unseated by first providing jurors with insight as to how prejudice works and by, second, eliciting from them individual public commitments to objectivity.

2. Postdeliberation survey. In addition to verdict and confidence in verdict, items in this survey assessed jurors' selfreported skills at persuasion. Questions like: "To what extent did you contribute to deliberation," and "To what extent did you assert your particular point of view" were rated on 9-point scales. With this information we may make some connection between a certain world view, dominance in groups, and verdict preferences. 
III. Results

A. Descriptive Statistics

Insert Table 1 about here

The descriptive statistics are displayed in Table 1. Forty one percent of the subjects convicted in their predeliberation verdicts, indicating that the case was slightly biased toward the defense. This is also evident from the case strength ratings. The mean prosecution and defense case strength ratings were close to the scale midpoint, although the defense's case was rated as slightly stronger. The predeliberation verdicts, postdeliberation verdicts, and case strength ratings were highly intercorrelated. Scores on the Juror Bias Scale and subscales were normally distributed and correlated in the expected direction with the culpability measures. Some of these correlations attained statistical significance.

B. Predeliberation verdict.

Predeliberation verdict served as the primary dependent variable in a two (Judge-federal $v$. Attorney-extended voir dire) by two (pretrial publicity $v$. no pretrial publicity) ANCOVA. Juror Bias Scale scores were covaried in light of their correlation with predeliberation verdict and in view of the possibility that subjects in the four conditions differed with respect to scores on that scale. 
C. Predeliberation Effects.

The adjusted cell means are plotted in Figure 1.

Insert Figure 1 about here

As predicted, the main effect for pretrial publicity was significant, $\underline{F}(1,61)=4.40, \underline{p}=.040$, eta-squared $=.06$. Subjects exposed to pretrial publicity were more likely to convict as compared with subjects exposed to no pretrial publicity. The main effect for voir dire was also significant, $E(1,61)=8.61, \mathrm{p}=.005$, eta-squared $=.12$, meaning that the attorney-extended voir dire elicited fewer convictions than did the judge-federal voir dire. The interaction did not approach statistical significance, $\underline{F}(1,61)=.22, \underline{p}=.64$, etasquared $=.002$, indicating that the effect of pretrial publicity was comparable in magnitude across the two voir dire conditions. In summary, pretrial publicity increased conviction rate and attorneyextended voir dire decreased conviction rate, but the attorney-extended voir dire failed to reduce the prejudicial effect of pretrial publicity. Similar patterns of results emerge using the case strength ratings and a scaled verdict (i.e., verdict combined with verdict confidence scores) as dependent variables as well as by covarying out for Juror Bias subscale scores.

Additional evidence for the prejudicial effect of pretrial 
publicity is evident in the analyses of the defendant culpability ratings obtained immediately after subjects read the publicity packets. Among the subjects exposed to pretrial publicity $(\underline{n}=38)$, perceived culpability of the defendant, rated just after reading the publicity, correlated $.36(\mathrm{~g}=.027)$ with predeliberation verdicts. Subjects who perceived the defendant to be more culpable--based on the publicity-were more likely to convict him. When the effect of Juror Bias Scale scores was removed, the correlation between culpability ratings (obtained immediately after reading the pretrail publicity) and predeliberation verdict dropped to $.22(\mathrm{p}=.166)$. While these findings suggest that exposure to prejudicial pretrial publicity increased perceptions of guilt, one might argue alternatively that the correlation between culpability ratings and predeliberation verdict reflects instead subjects' commitment to their initial verdict choice.

D. Postdeliberation Effects.

Although I conducted inferential analyses on postdeliberation verdict, these analyses must be viewed with caution. These data violate the independence assumption. ANCOVA was used to examine the influence of PTP on voir dire as reflected in postdeliberation verdicts. Juror Bias Scale scores served as the covariate. Significant main effects were found for PTP, $\underline{F}(1,64)=$ 9.12, $p=.004$, eta-squared $=.119$, and for voir dire, $\underline{F}(1,64)=4.08$, $p=.048$, eta-squared $=.053$. The main effect for deliberation, 
however, was nonsignificant, $\underline{F}(1,63)=.78, \underline{p}=.382$, eta-squared $=$ .01 . The voir dire X PTP interaction was also significant, $\underline{F}(1,64)=$ 4.32, $p=.042$, eta-squared $=.056$. The cell means (adjusted for JBS scores) are plotted in Figure 2. The interaction shows that the effect for PTP is significantly greater within the attorney-extended condition than within the judge-federal condition.

Does deliberation affect subjects' judgments? In order to directly address this question, a three-way mixed design MANOVA was conducted with two between-subject variables, PTP and voir dire, and one within=subject variable, deliberation (pre $v$. post). The dependent variable was verdict. This analys is examines whether deliberation qualifies any of the above effects. The deliberation X PTP interaction was nonsignificant, $\underline{F}(1,63)=.71, \underline{p}=.402$, eta-squared $=.01$, indicating that the magnitude of the PTP effect was unchanged by deliberation. Likewise, the deliberation $x$ voir dire interaction was nonsignificant, $\underline{F}(1,63)=.71, \underline{p}=.402$, eta-squared $=.01$, indicating that the magnitude of the voir dire effect was not qualified by deliberation. The three-way interaction, however, was significant, $\underline{F}$ $(1,63)=6.59, \mathrm{p}=.013$, eta-squared $=.09$, indicating that the two-way interaction between voir dire and PTP was significantly larger after rather than before deliberation (cf. Figures 1 and 2). As the univariate ANCOVAs showed, the PTP $X$ voir dire interaction was nonsignificant for predeliberation verdicts but significant for 
postdeliberation verdicts. Again, analyses involving postdeliberation verdict must be viewed with caution, as the data are not independent. Finally, subjects in each of the four experimental conditions were randomly assigned to one of two juries yielding a total of eight deliberating juries. Juries in (a) judge-federal voir dire/no PTP voted not guilty, hung; (b) attorney-extended voir dire/no PTP voted not guilty, not guilty; (c) judge-federal voir dire/PTP voted hung, not guilty; and (d) attorney-extended voir dire/PTP voted guilty, not guilty. Because these grouped data do not constitute a large enough sample, they were not subjected to statistical analysis.

IV. Discussion

\section{A. Major Findings}

The present study asked two important questions: Does prejudicial pretrial publicity produce bias which may impair juror objectivity and, if it does, can voir dire remedy its untoward effects. In terms, then, of its two-fold thrust, the present study found, first of all, that subjects exposed to prejudicial pretrial publicity are more likely to convict than those who read neutral stories. I found, secondly, that prejudgment of a general nature (e.g., confusion about legal concepts) may be neutralized by an extended, attorney-conducted voir dire, but that prejudice specifically created by exposure to inflammatory news stories is not offset by an extended voir dire format. While these results suggest that insights made available 
during the attorney-extended voir dire caused jurors to hold the State more stringently to its burden of proof, without independent evidence, I cannot be sure. Subjects were not asked directly to recall or to weight the information received during voir dire. However, because substantive content (i.e., clarifying misunderstood legal concepts) constitutes the biggest difference between the judge-federal and attorney-extended voir dire, I inferred that insights provided by the attorney account for the differences in predeliberation verdicts.

One could alternatively argue that, because in the extended voir dire the attorney attempted to establish rapport, subjects acquitted simply because they liked the attorney. Whether the decision to acquit was the result of subjects holding the State more stringently to its burden or the result of rapport established between the attorney and subjects, the point to be made is that procedural change (i.e., extended, attorney-conducted voir dire) benefitted defense counsel's client. Given the position taken here, namely that trial adversaries are obliged to do whatever they legally can to protect their client's interests, these findings support the contention that justice has been served.

1. The remedial effect of deliberation on prejudice created by media. Questioned also was the potential remedial effect of jury deliberation on prejudice created by incriminating news stories. If, as the court assumes, the deliberation 
process safeguards defendants against the damaging effects of prejudicial publicity then I should have found a smaller pretrial publicity effect for post- versus pre-deliberation verdict. This, however, was not the case. I found, as did earlier research, that the effect for pretrial publicity was greater for postdeliberation than it was for predeliberation verdicts, meaning that deliberation exaggerated media effects. That this exaggerated PTP effect in postdeliberation verdicts was significantly greater among subjects in the attorneyextended, as compared with the judge-federal, voir dire condition is more difficult to explain.

As an ad hoc explanation for this unpredicted finding, the classic polarization effect is certainly one possibility (Burnstein \& Vinokur, 1975, 1977). Having either read or not read prejudicial news stories, subjects had already formed or had not formed opinions regarding the defendant's culpability. Group polarization theory predicts that group debate (i.e., deliberation in this case) will strengthen and thereby polarize subjects' originally held opinions. This means that subjects for whom the publicity created impressions of guilt and subjects for whom no such prejudgments have been formed, will assert their opinions more confidently after debate. Why, however, is there no evidence of polarization in the judge-federal voir dire? Again, group polarization is the result of strengthening one's previously held position on some issue. Irrespective of voir dire 
condition, subjects either had or had not been exposed to prejudicial pretrial publicity. However, unlike subjects in the attorney-extended voir dire, subjects in the judge-federal condition did not benefit from the attorney's attempts to clarify confusing legalities during voir dire. There is a sense in which the clearing up of commonily misunderstood legal concepts functioned to inoculate (McGuire, 1961, 1964) subjects, who did not read publicity, against persuasion attempts made by those who had and who believed, even before the trial, that the defendant was guilty. Subjects, in the judge-federal voir dire, who were not exposed to publicity probably had no opinion as to the defendant's guilt. Without benefit either of inoculation, subjects voir dired by the judge who had not read prejudicial publicity were unable, during deliberation, to resist persuasive arguments made by subjects who had read and who believed, based on the media coverage, that the defendant was guilty.

Hastie, Penrod, and Pennington (1983), also interested in why people change their minds during deliberation, discuss similar findings in terms of knowledgeability, confidence, and susceptibility to social influence as documented in classic social psychological studies of conformity and persuasion (e.g., Deutsch \& Gerard, 1955; Sherif, 1935). Hastie et al. (1983) found that jurors were more influenced by information about legal issues (e.g., presumption of innocence and standard of proof) than by information about the trial evidence, 
because, they reasoned, jurors are generally confident that they understand what happened during the crime event (we draw conclusions about causes of events all the time) but are less so about applications of law. Lacking such relevant information, jurors can be coerced into agreement by those whose beliefs are confidently expressed as was the case with subjects (in the present study) who had read prejudicial publicity (Sherif, 1935).

2. Problems with dichotomous variables. There are some who take issue with use of a dichotomous dependent variable arguing that, because it restricts variability, the variable is less sensitive (Penrod \& Cutler, 1987). Still others point out that a juror's task, in the real world, is to make a dichotomous decision and that to alter it for experimental purposes is inappropriate (Carroll et al., 1986). Attempting to assuage critics on either side of this issue, subjects rendered dichotomous verdict decisions and expressed confidence (on 9point scales) in their decision. Combining the two sources of independent information, I produced a scaled-predeliberation verdict measure which, as it turns out, supported my original (unscaled) findings.

3. Does voir dire neutralize expectancy confirmation.

In their recent review, Pennington and Hastie (1990) contrast the earlier algebraic adjustment process accounts and the new, cognitive, explanation-based accounts of jury decision making. Integral 
to the explanation-based approach is the recognition that trial evidence is evaluated in terms of jurors' world views. As stated, the main effect for voir dire suggests that partiality of a general nature can be offset by a probing and informative voir dire. Jurors, regardless of which media they read in advance, convicted less in the attorney-extended conditions meaning that what they heard during voir dire served to clarify previously held misconceptions. By explaining what is meant and how generally to apply legal concepts such as presumption of innocence, burden of proof, and reasonable doubt in particular, the extended voir dire facilitated juror impartiality. Now jurors were able to objectively evaluate trial testimony and carefully apply the law as instructed by the trial judge.

Resisting neutralization, however, the specific expectancy created by prejudicial pretrial publicity was not offset by voir dire. The main effect for pretrial publicity was not qualified by voir dire meaning that prejudicial impressions created by inflammatory news stories persisted even after subjects were told that facts reported in the media are not evidence. As suggested in the expectancy confirmation literature (Lord, Ross, \& Lepper, 1979; Darley \& Fazio, 1980), subjects' ability to weigh the case facts objectively was influenced by prejudicial media coverage. These findings are not meant to be discouraging. The fact is that extended voir dire did affect certain juror behaviors. Perhaps the oral examination simply was not thorough 
enough. There is, then, reason to believe that with more time spent explaining case facts and with greater attention to individual jurors, voir dire could eliminate even the specific prejudice created by pretrial publicity.

\section{B. Policy Implications}

\section{Comparisons between judge-minimal and}

$$
\text { attorney-extended voir dire. In principle, voir dire }
$$

safeguards a criminal defendant's right to trial by an impartial jury but, in reality, juror questioning in the minimalist federal model may be so constrained that disclosure of juror prejudice is impossible (Moran, Cutler, \& Loftus, 1990). Without sufficient probing, jurors will not be disqualified either for cause or peremptorily meaning that verdicts may be influenced by undetected juror bias. Fundamentally, this constitutes a miscarriage of justice. Nowhere, in the law, is the breadth and depth of voir dire questioning specified, but if fairness is what the law demands then voir dire must probe deeply enough to disqualify jurors, if not for cause, then peremptorily. In fact, the courts acknowledge that the peremptory challenge is "one of the most important of the rights secured to the accused [and] a necessary part of trial by jury" (Swain V. Alabama, 1965, p. xxx). To use peremptory challenges wisely, attorneys need sufficient latitude to probe into the background and attitudes of venirepersons (United States v. Dellinger, 1972). If it can be shown that information gleaned from extended voir 
dire enables attorneys to maximize the use of their challenges, then perhaps judges will be persuaded to allow extended voir dire.

Jury researchers have found support for use of the expanded, attorney-conducted voir dire at least insofar as challenge for cause is concerned. For example, when compared with a restricted (judgeconducted, en masse) voir dire, the expanded (attorney-conducted, sequestered) version, in one third of all capital trials between 19751980 in Kentucky, yielded more challenges for cause by the defense (Nietzel \& Dillehay, 1982). And based on statistical evidence from a number of trials, Christie (1976) suggests that when voir dire questioning is not adequately developed, attorneys cannot successfully challenge jurors for cause.

Differences between the minimal (judge-conducted) and extended voir dire (attorney-conducted) formats are glaring in terms of both the quality, quantity, and relevance of questions asked, and, as already suggested, the minimal voir dire yields little information from each juror on which to base peremptory challenges (Moran, Cutler, \& Loftus, 1990). Typically, questioning in a minimal voir dire is limited to demographics such as age; place of residence; occupation; marital status; spouse's occupation; children's ages and occupations; and membership in social groups. Judges usually conclude questioning with a presentation of certain case facts after which jurors are asked if they can render impartial judgments. Few say they cannot. Rather than 
disqualifying for cause those who do, the judge "rehabilitates" them; that is, jurors who indicated inability to be fair are pressured into believing that they can be. Although there is some evidence that information learned during a minimal voir dire can predict convictionproneness, predictive validity is modest (Moran \& Comfort, 1982; Moran \& Cutler, 1989). Compared with basic demographic information, personality attributes; attitudes; authoritarian tendencies; case-relevant opinions and experiences; attitudes toward crime; and political views are better predictors of tendency to convict (Moran \& Cutler, 1989; Moran, Cutler, \& Loftus, 1990). Such information is often made available during extended voir dire.

2. Proposed legislative changes in voir dire. Results of this study are relevant to issues recently under senatorial debate. Early in 1983, Senator Howell Heflin of Alabama introduced Senate Bills 386 and 677 which proposed amendments to Federal Rules of Procedure $24(a)$ and $47(a)$, respectively. Both bills sought to change the conduct of voir dire in federal district courts. As it stands, trial judges control the nature and extent of voir dire questioning; they also decide who asks the questions. A 1977 survey of federal judges revealed that $75 \%$ do not permit lawyers to conduct oral examination (Bermant, 1977). In the aforementioned two bills, lawyers argued the right to oral participation in jury selection on the grounds that without it they cannot make intelligent use of peremptory challenges. Their rationale 
is simple: unless defense counsel is allowed to probe and disqualify the venire for prejudice which may be obvious or subtle, they cannot adequately protect their client's Sixth Amendment right. Any infringement of this right constitutes reversible error without the need to show prejudice (United States V. Blanton, 1978). Neither of the bills passed.

3. Bermant's argument. That criminal defendants are entitled to trial by a fair jury is not the issue here--it is an inalienable right--the issue is whether or not extended, attorneyconducted voir dire makes trial by a fair jury more likely. Expressing his concern, Bermant vigorously justifies continued control of voir dire by trial judges. Handing control of jury selection over to trial lawyers would not make a fair trial more likely but would, according to Bermant, make the justice system itself vulnerable to the sort of attorney abuses that are inherent in adversarial advocacy. The threat to "fairness" comes not from undetected juror prejudice, Bermant goes on to say, but comes from overzealous adversaries who are paid to win at all costs. The values that are at odds in the voir dire issue, then, are the value of a fair jury versus the value of adversary advocacy. It is interesting that here Bermant characterizes fairness and advocacy as opposing values when earlier he discusses them not as competing values but as alternative threats. The present study's findings have direct bearing on this issue and since Bermant argues several of its relevant 
aspects, I will state and attempt to rebut his position point by point.

Case law clearly states that, regardless of who does the asking, the oral examination "must be thorough enough to allow the intelligent exercise of peremptory challenges by trial counsel" (Bermant, 1977, p. 298). Not surprisingly, Bermant questions what is meant by "intelligent exercise." As is often the case in law, its utterly abstract language defies understanding. What Bermant soon makes clear is that, for him, the real issue is not whether attorneys acquire enough useful information during voir dire to protect their clients' rights, but whether they are skilled enough, given exhaustive information, to ferret out deep-seated prejudice in jury panelists. There is no evidence, claims Bermant, to suggest that attorneys can intuit who, from among the venire, may or may not be favorably disposed toward their client.

One often cited study--and there are only a few--that directly examined these issues found that lawyers did not effectively use voir dire to disqualify biased jurors (Zeisel \& Diamond, 1978). Zeisel and Diamond (1978) employed shadow juries composed of peremptorily challenged jurors from the actual panel or randomly selected jurors, who watched complete trials along with the actual juries. In only three of the twelve trials for which data were collected did attorney challenges favorably influence jury composition (but the judges in these cases did not support the juries' verdicts). 
Zeisel and Diamond concluded that attorney performance was highly variable and that, across trials, attorneys sat as many unfavorable jurors as they excused. There were methodological problems as well, for example, data had to be reconstructed making generalization to everyday legal practice imprudent.

Bermant points out, as he reasonably should, some reasons why Zeisel and Diamond's (1978) discouraging conclusions should not be taken as the final word. First, and this bears significantly on the problem, the lawyers in Zeisel and Diamond's study were excluded from participation in the voir dire procedure. If the issue is whether or not lawyers can make good use of personally conducted juror interviews, but they are denied the interviews, how can inferences regarding lawyer efficacy be made from Zeisel and Diamond's findings? Bermant is careful to point out at least some of this but then goes on to say:

Nevertheless, this research remains the strongest available and a model for those who would seriously try to promote change in the current federal practice by bringing positive evidence to bear in favor of their position ( $p .299)$.

In my opinion, Bermant is making an unjustifiably strong case given that "there is only a beginning of empirical research on the skills of lawyers to utilize the examination effectively" (p. 299) and that the research he cites does not fairly test the issue at hand. We cannot rule out the possibility, and this is the second reason why much 
to-do over Zeisel and Diamond's findings is unwarranted, that given a fair test attorneys might indeed prove to be effective. Using this same reasoning, one cannot rule out the possibility that, if assisted by scientific jury selection, attorneys may well utilize voir dire effectively (Moran, Cutler, \& Loftus, 1990).

4. Statements made by the proponents of change. As a way of stating his case, Bermant reproduces testimony that was given by John Ackerman before the Senate Judiciary Committee in support of the proposed rule changes. As past president of the NACDL and testifying on its behalf, Ackerman cited Broeder's (1965) data which showed that jurors, during the voir dire examination, were not entirely forthright in their responses. Agreeing that juror dishonesty--to the degree that it exists--poses a serious problem, Bermant asks and answers three relevant questions. First, does public examination in a court of law inhibit juror honesty? Second, does the role or status of the examiner influence juror responses? And, third, does skillful questioning make juror honesty more likely irrespective of role?

Bermant says no one knows whether judges or lawyers inhibit jurors more and even if it were the case that judges do inhibit juror honesty the problem will not be solved by shifting control of voir dire to lawyers, but by training judges to conduct good interviews. My response to these claims is mixed. Subsequent research by Jones (1987), found that subjects (who were interviewed by either a judge or an 
attorney) changed their answers nearly twice as much when questioned by a judge. These findings speak, at the same time, to the first and last of Bermant's three questions; that is, yes, judges may inhibit frank juror disclosure and, no, the skill of the interviewer, irrespective of role or personal style, does not make the important difference. In Jones's study (1987), the content and length of the voir dire was identical for both the judge and attorney. Even if, as Bermant recommends, judges were trained to elicit probative information from jurors making trial by a fair jury more likely, the "key ingredient," as he puts it, "will be the judge's willingness to pursue improved voir dire methods" (p. 304). In terms of policy, consideration of this change, at the very least, is what I would hope my findings ultimately inspire.

Referring to what Bermant calls the "most significant and serious argument" (p. 304) among those offered in Ackerman's testimony, is the claim that trial judges do not know how to ask questions. The point being of course, that without sufficient probative information, attorneys cannot intelligently exercise peremptory challenges. Here the argument returns to Bermant's initial challenge; that is, can attorneys do any better and, if they could would a "fair" jury be the net result? On both counts, Bermant thinks not. With tongue in cheek, Bermant ridicules an unfounded social psychological claim that judges, unlike lawyers, do not know enough about the psychological subtleties of the 
cases at bar to ask meaningful questions (e.g., United States v. Ible, 1980). Granting that certain politically or ideologically charged criminal cases, where the evidence is thin, may require a sensitive and skilled probe for juror prejudice, Bermant disagrees that routine cases require such a probe or that attorneys can or should be the persons to conduct it. Bermant insists that claims made by those who advocate changing the conduct of voir dire are specious, once again, on the grounds that they are unsupported by empirical data. But there are two sides to this claim; absent empirical evidence, one may not conclude that lawyers can or cannot conduct more productive interviews. Despite failure to find empirical support, attorneys maintain that intuition and experience help them to identify and challenge unfavorable jury panelists. Why does this confidence persist if in fact attorney selection methods are unsuccessfu1? Because attorneys do not get relevant feedback (i.e., they never really know if they challenged the right individuals) they may attribute a favorable verdict to their selection strategy when in reality the desired verdict may be the result of (a) weak evidence on the opposing side and/or (b) a we11-presented case.

\section{Statements made by the opponents of change. The} position of those who oppose change centers on questions of time and abuse. While Ackerman, speaking for trial lawyers, claimed that attorney-conducted voir dire takes approximately $10 \%$ of total trial 
time, Trott (citing from New York Governor Hugh Carey's Executive Advisory Commission on the Administration of Justice) reported that voir dire under the control of attorneys can take as much as one third of total trial time. In a justice system whose calendars are already severely backlogged, it is difficult to justify additional time expense especially when, left to their own devices, lawyers "will abuse the examination, the panel members, and the patience of the public who also await their days in court" (p. 315). In short, then, concerns expressed by the Judicial Conference of the United States, are over the distinction between probative and didactic use of the voir dire examination. In their opinion, trial lawyers, if given control of voir dire, will use it for didactic purposes and while criminal defendants are protected under the Sixth Amendment, there is no safeguard against illegal use of voir dire.

Despite the fact that there is no empirical evidence to support these claims, Bermant confidently asserts that good advocates simply could not help but misbehave. For if done effectively, lawyers can select juries that are sympathetic to their clients but, in so doing, move from an impartial jury to a partial one. Posing a grave threat to the justice system, then, are defense counsels who strive to do whatever will achieve victory for their clients. Countering this claim, Ackerman wonders:

Why is it that judges who do such a marvelous job of 
controlling improper questions of witnesses, improper opening statements and improper argument, cannot control improper voir dire (p. 307)?

As for the issue of time itself, Ackerman asks if time saved on voir dire is worth the sacrifice; with the extra time, a defendant may get a fair and impartial jury. Actually, the solution may be simple. In fact, a prime argument made by trial consultants in favor of extended voir dire, is that by using voir dire questionnaires, the duration of the jury selection can be shortened.

Finally, and this is the official position of the Department of Justice, that "the prevailing practice [most federal judges conduct the examinations entirely themselves] has proven to be fair and economical" (p. 310). Might one logically respond to this statement just as Bermant responds to statements made by those who oppose his views, namely by asking where the evidence is. Saks (1989), in his analysis and evaluation of legal policy, points out the law's tendency to make and change policy without benefit of data. Using examples such as insanity defense reform, legislation to solve the liability crisis, and sentencing guidelines, Saks suggests that, in making decisions that affect our everyday lives, the law (including lawyers, judges, and legislators) does not know what information is relevant, where to find it, or how to evaluate it. The thrust of Bermant's position seems to be founded on the same shaky ground. 
While Bermant seems confident that his argument is a strong one, I find it unsatisfying. Much of what he dismisses as either already known or else unprovable constitutes prime fodder for empirical examination. There are three things that we know already. First, Jones did find that attorneys, as compared with judges, elicited more candid juror disclosure. Second, extended (versus minimal) voir dire produced more probative information from which to base intelligent peremptory challenges (Moran, Cutler, \& Loftus, 1990). And third, attorneyextended (versus judge-federal) voir dire neutralized the effects of general preconceptions on juror verdicts.

\section{Suggestions for Further Research}

Convinced that only judges can guarantee the integrity of the voir dire examination, Bermant recommends leaving the current federal rules as they are. I, on the other hand, am optimistic that voir dire, insofar as it insures impartiality, can be improved. These findings invite investigation along two separate and important lines of inquiry. First, can the form and substance of the oral examination itself, irrespective of the interviewer, favorably influence jury composition? And second, given that the interview effectively flushes out juror prejudice, will it be used more productively by the lawyer, the judge, or via venireperson questionnaire?

The present study found that attorney-extended voir dire affected prejudice of a general nature but not prejudice specifically 
created by pretrial publicity. These results call for an even more expanded juror interview. By exposing the ways in which incriminating media create prejudice, voir dire could undermine its untoward effects. The first leg of the proposed research, then, should again pit a minimalist voir dire against a more expanded version. Whereas the present study limited counsel's voir dire to one hour, in the next study defense counsel will question individual jury panelists at length either en masse or sequestered. It will be interesting to see whether the public or the private forum produces the fairer juror. Social psychologists hold that public commitments to objectivity make jurors more accountable to each other. On the other hand, it is easy to imagine that disclosures of prejudice would be inhibited by the presence of others. Besides commitments to uphold the law and public disclosures of juror bias, the expanded voir dire should increase the volume of usable information for exercising peremptory challenges.

Having constructed the optimal juror interview and tested its effectiveness, the second leg of the proposed research will determine whether its use is maximized by the judge or by the lawyer. With this second test, two of Bermant's original three questions can be addressed, namely is the "elicitation of honest answers affected by the role of questioner and is the extent to which the elicitation of candid answers affected by the interviewing skill of the questioner, irrespective of role" (p. 304). Answers to these questions should put 
some of the conjecture to rest and, more importantly, this research should quiet the cry for empirical findings that appears throughout the psycholegal literature--not to mention Bermant's argument. Finally, should we demonstrate that extended voir dire--conducted by whomever--is more likely to safeguard a defendant's Sixth Amendment rights then judges, in the service of justice, may be persuaded to permit its use in their courts. 
Table 1

Descriptive Statistics

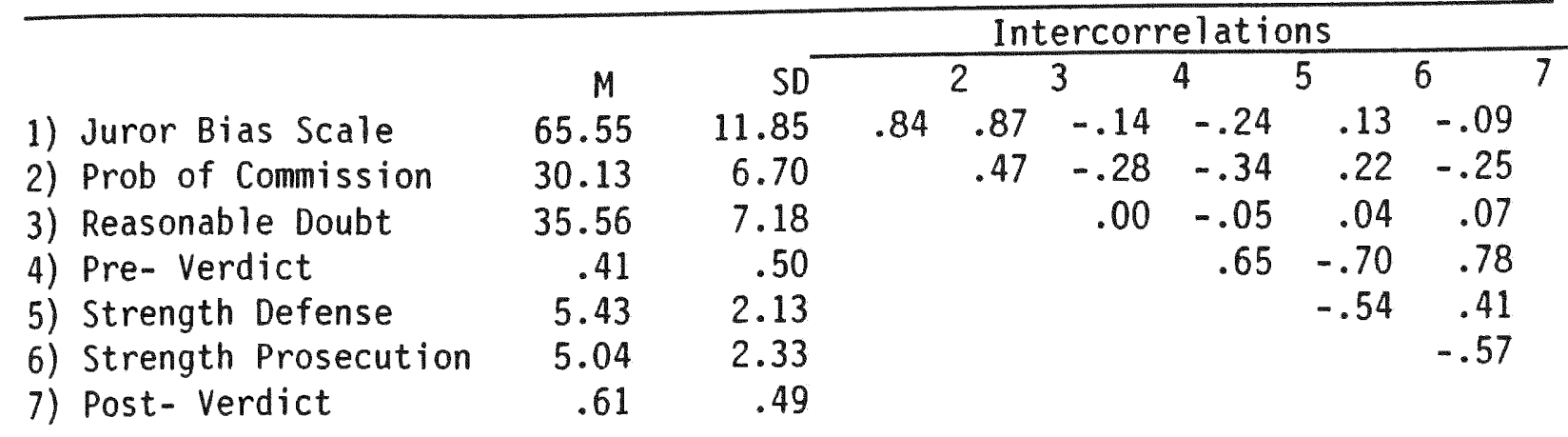

Table 2

Predeliberation Verdict

\begin{tabular}{rccccccc}
\hline VD & PTP & Constant & VD & PTP & & Acquit & Convict \\
-1 & -1 & .59 & -.17 & .12 & $=$ & .54 & .46 \\
-1 & 1 & .59 & -.17 & -.12 & $=$ & .30 & .70 \\
1 & -1 & .59 & .17 & .12 & $=$ & .88 & .12 \\
1 & 1 & .59 & .17 & -.12 & $=$ & .64 & .36 \\
\hline
\end{tabular}

Key

VD: Judge-federal $=-1$

Attorney-extended $=1$

PTP: No $=-1$

Yes $=1$

Table 3

Postdeliberation Verdict

\begin{tabular}{rrcrrrrl}
\hline VD & PIP & Constant & VD & PTP & VP & Acquit & Convict \\
-1 & -1 & .64 & -.13 & .17 & -.12 & .56 & .44 \\
-1 & 1 & .64 & -.13 & -.17 & .12 & .46 & .54 \\
1 & -1 & .64 & .13 & .17 & .12 & 1.00 & .00 \\
1 & 1 & .64 & .13 & -.17 & -.12 & .48 & .52 \\
\hline
\end{tabular}

VD: Judge-federal $=-1$

Attorney-extended $=1$

PTP: No $=-1$

Yes $=1$ 


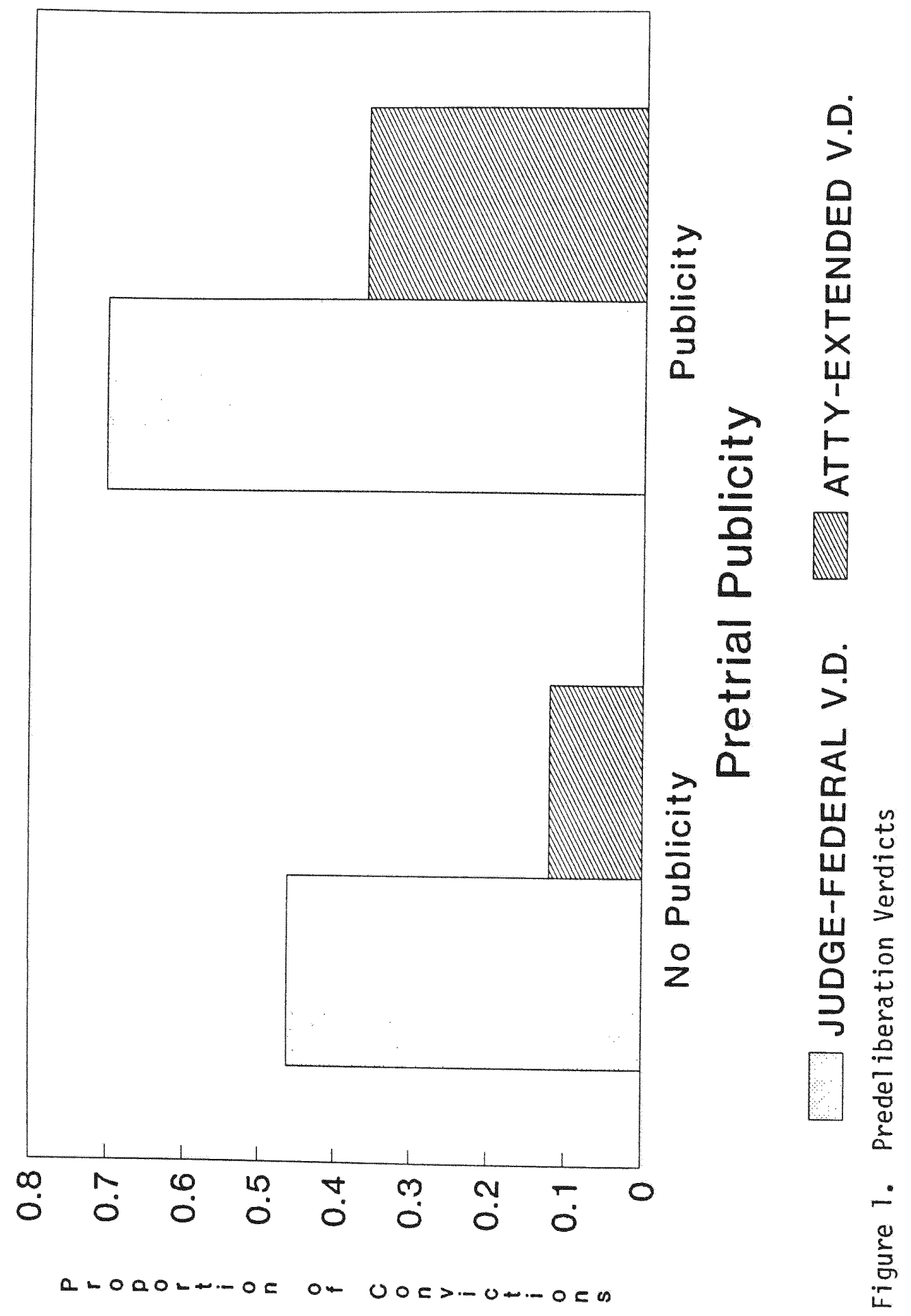




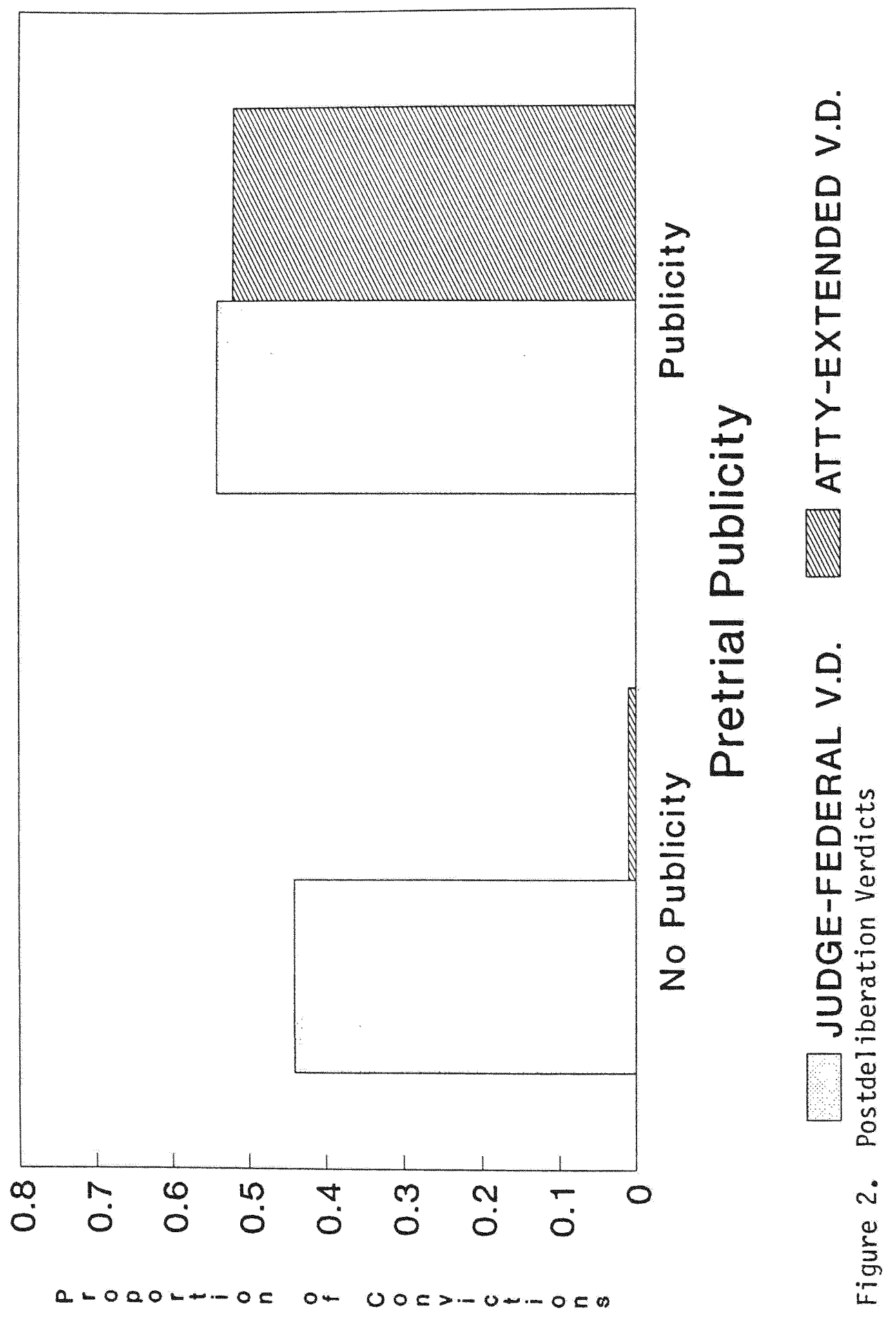


APPENDIX A

Demographics and Juror Bias Scale

Name:

Student ID \#:

Professor:

Phone Number:

Please answer each question to the best of your ability. You must not ask anyone for help.

We are sure that you understand the importance of juries to our American system of justice. We are confident that you also appreciate your duty as a citizen to serve as a juror if you are eligible. Your cooperation in completing and returning this "Juror Questionnaire" is a part of that duty. Without your help our courts cannot operate properly in accordance with the United States Constitution.

PLEASE PUT YOUR NAME AND SOCIAL SECURITY NUMBER ON THE RESPONSE SHEET AND FILL IN THE CORRESPONDING BUBBLES. THE FIRST PART OF THE QUESTIONNAIRE SOLICITS DEMOGRAPHIC INFORMATION. PLEASE INDICATE ALL ANSWERS ON THE RESPONSE SHEET PROVIDED FOR YOU. MAKE SURE YOU ANSWER EVERY QUESTION.

Please answer the following demographic questions.

1. Your Sex:

A) Male

B) Female

2. Your Age:
A) $17-29$
B) $30-39$
C) $40-49$
D) $50-59$
E) $60+$

3. Your Race: A) White

B) Black

C) Hispanic

D) Other (specify)

4. Please indicate your marital status.
A) Never married
B) Divorced (currently single)
C) Divorced (currently remarried) 

D) Married (never divorced)
E) Widowed

5. How many children do you have?
A) None
B) One or Two
C) Three
D) More than three

6. What is your educational level?
A) Post-graduate college work or degree
B) College degree
C) Some college but didn't complete program
D) High School graduate
E) Less than high school graduate

7. What is your current political preference (not necessarily your registration)?
A) Democrat
B) Republican
C) Independent
D) Other (specify)

8. Aside from your political affiliation, how would you evaluate your political views?
A) Liberal 
B) Slightly Liberal

C) Slightly conservative

D) Conservative

9. Have you ever served on a jury in a criminal case?
A) Yes
B) No

10. Have you ever served on a jury in a civil case?
A) Yes
B) No

11. Are you a registered voter?
A) Yes
B) No

The following is a list of personal opinions that are descriptive of some people, less descriptive of others. There are no right or wrong answers. The answer that best describes you or your opinion is the right answer. It is usually best to answer the questions rather quickly rather than spending a long time thinking about them. Some answers may be hard to decide upon. Please give your best personal response even if you are somewhat unsure. IT IS IMPORTANT TO ANSWER ALL QUESTIONS.

12. If a suspect runs from the police, then he probably committed the crime.
strongly agree
$\begin{array}{lllllll}0 & 1 & 2 & 3 & 4 & 5 & 6\end{array}$
strongly
disagree 
13. A defendant should be found guilty if 11 out of 12 jurors vote guilty.

strongly $\begin{array}{lllllllll}\text { agree } & 0 & 1 & 2 & 3 & 4 & 5 & 6 & \text { disagree }\end{array}$

14. Too often jurors hesitate to convict someone who is guilty out of pure sympathy.

$\begin{array}{ccccccccc}\text { strongly } & & & & & & & & \begin{array}{c}\text { strongly } \\ \text { disagree }\end{array}\end{array}$

15. In most cases where the accused presents a strong defense, it is only because of a good lawyer.

strongly strongly $\begin{array}{lllllllll}\text { agree } & 0 & 1 & 2 & 3 & 4 & 5 & 6 & \text { disagree }\end{array}$

16. The death penalty is cruel and inhumane.

$\begin{array}{ccccccccc}\begin{array}{c}\text { strongly } \\ \text { agree }\end{array} & 0 & 1 & 2 & 3 & 4 & 5 & 6 & \begin{array}{l}\text { strongly } \\ \text { disagree }\end{array}\end{array}$

17. Out of every 100 people brought to trial, at least 75 are guilty of the crime with which they are charged.

strongly strongly $\begin{array}{lllllllll}\text { agree } & 0 & 1 & 2 & 3 & 4 & 5 & 6 & \text { disagree }\end{array}$

18. For serious crimes like murder, a defendant should be found guilty so long as there is a $90 \%$ chance that he committed the crime.

strongly agree

$\begin{array}{llllllll}0 & 1 & 2 & 3 & 4 & 5 & 6 & \begin{array}{l}\text { strongly } \\ \text { disagree }\end{array}\end{array}$ 
19. Defense lawyers don't really care about guilt or innocence, they are just in business to make money.

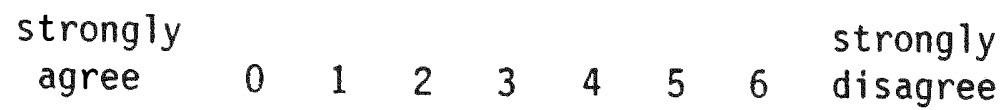

20. Generally, the police make an arrest only when they are sure about who committed the crime.

strongly

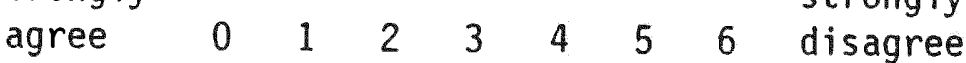

21. Circumstantial evidence is too weak to use in court.

strongly

agree $\quad \begin{array}{llllllll}0 & 1 & 2 & 3 & 4 & 5 & 6 & \text { disagree }\end{array}$

22. Many accident claims filed against insurance companies are phony.

strongly

$\begin{array}{lllllllll}\text { agree } & 0 & 1 & 2 & 3 & 4 & 5 & 6 & \text { disagree }\end{array}$

23. The defendant is often a victim of his own bad reputation.

$\begin{array}{ccccccccc}\begin{array}{c}\text { strongly } \\ \text { agree }\end{array} & 0 & 1 & 2 & 3 & 4 & 5 & 6 & \begin{array}{l}\text { strongly } \\ \text { disagree }\end{array}\end{array}$

24. If the grand jury recommends that a person be brought to trial, then he probably committed the crime.

strongly

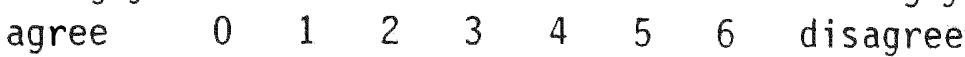


25. Extenuating circumstances should not be considered--if a person commits a crime, then that person should be punished.

strongly $\begin{array}{lllllllll}\text { agree } & 0 & 1 & 2 & 3 & 4 & 5 & 6 & \text { disagree }\end{array}$

26. Too many innocent people are wrongfully imprisoned.

$\begin{array}{ccccccccc}\begin{array}{c}\text { strongly } \\ \text { agree }\end{array} & 0 & 1 & 2 & 3 & 4 & 5 & 6 & \begin{array}{l}\text { strongly } \\ \text { disagree }\end{array}\end{array}$

27. If a majority of the evidence--but not all of it--suggests that the defendant committed the crime, the jury should vote not guilty.

$\begin{array}{ccccccccc}\begin{array}{c}\text { strongly } \\ \text { agree }\end{array} & 0 & 1 & 2 & 3 & 4 & 5 & 6 & \begin{array}{c}\text { strongly } \\ \text { disagree }\end{array}\end{array}$

28. If the defendant committed a victimless crime like gambling or possession of marijuana, he should never be convicted.

strongly $\begin{array}{lllllllll}\text { agree } & 0 & 1 & 2 & 3 & 4 & 5 & 6 & \text { disagree }\end{array}$ 
APPENDIX B

Pre- and Postdeliberation Scale

Name:

Prof:

I.D. \#:

Please respond to the following questions as if you were called to jury duty in this case. Indicate your responses by either circling the appropriate answer or by entering your answer in the space provided.

1. Right now, if I were to ask you to state your verdict, what verdict would it be? (circle one)

$$
\text { GUILTY NOT GUILTY }
$$

2. How confident are you that your verdict is correct?
not at all
$\begin{array}{lllllllllll}\text { confident } & 1 & 2 & 3 & 4 & 5 & 6 & 7 & 8 & 9 & \text { confident }\end{array}$

3. How would you rate the overall strength of the Defense's case offered at trial?

$\begin{array}{lllllllllll}\text { very weak } & 1 & 2 & 3 & 4 & 5 & 6 & 7 & 8 & 9 & \text { very strong }\end{array}$

4. How would you rate the overall strength of the

Prosecution's case offered at trial?

$\begin{array}{lllllllllll}\text { very weak } & 1 & 2 & 3 & 4 & 5 & 6 & 7 & 8 & 9 & \text { very strong }\end{array}$

5. How persuasive was David Jones as a witness?

not at all extremely $\begin{array}{lllllllllll}\text { persuasive } & 1 & 2 & 3 & 4 & 5 & 6 & 7 & 8 & 9 & \text { persuasive }\end{array}$

6. How persuasive was Sally Roberts Smith as a witness?

not at all

extremely

$\begin{array}{lllllllllll}\text { persuasive } & 1 & 2 & 3 & 4 & 5 & 6 & 7 & 8 & 9 & \text { persuasive }\end{array}$

7. How persuasive was Officer Overby as a witness for the Prosecution?

not at all

persuasive $\begin{array}{lllllllllll}1 & 2 & 3 & 4 & 5 & 6 & 7 & 8 & 9 & \text { persuasive }\end{array}$ 
8. How persuasive was the pathologist Helen Young as a witness for the Defense?

not at all

persuasive $1 \begin{array}{llllllllll}1 & 2 & 3 & 4 & 5 & 6 & 7 & 8 & 9 & \text { persuasive }\end{array}$

9. How would you rate the overall ability of the lawyer for the Prosecution?

not very able $\begin{array}{lllllllllll}1 & 2 & 3 & 4 & 5 & 6 & 7 & 8 & 9 & \text { very able }\end{array}$

10. How would you rate the overall ability of the lawyer for the Defense?

not very able $\begin{array}{lllllllllll}1 & 2 & 3 & 4 & 5 & 6 & 7 & 8 & 9 & \text { very able }\end{array}$

11. How strong was your interest in this case?

not at all

$\begin{array}{lllllllllll}\text { interested } & 1 & 2 & 3 & 4 & 5 & 6 & 7 & 8 & 9 & \text { interested }\end{array}$

12. How strong was your involvement in this case?

not at all

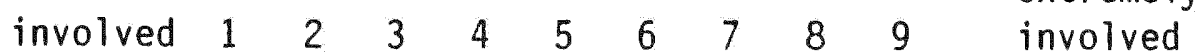

13. How strong was your commitment to seek the truth (i.e., weigh only the evidence presented at trial) in this case?

not at all

$\begin{array}{lllllllllll}\text { committed } & 1 & 2 & 3 & 4 & 5 & 6 & 7 & 8 & 9 & \text { committed }\end{array}$

14. To what extent did the judge's instructions help you reach a verdict?

not at ail $\begin{array}{lllllllllll}\text { helpful } & 1 & 2 & 3 & 4 & 5 & 6 & 7 & 8 & 9 & \text { helpful }\end{array}$

15. How well did you understand the judge's instructions to the jury?

Could not

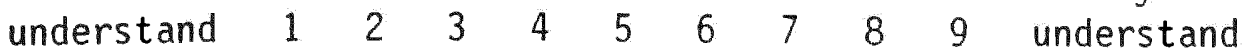
STOP: DO NOT GO ANY FURTHER AT THIS TIME 
Name:

Prof:

I.D. \#:

Prof:

16. What was your initial (personal) decision in the case after deliberation? (circle one)

GUILTY NOT GUILTY

17. What was the jury's final decision in the case? (circle one)

GUILTY NOT GUILTY

18. Were you the foreman in this case? (circle one)

YES NO

19. To what extent were you personally responsible for changing other jurors' decisions?

not at all

$\begin{array}{lllllllllll}\text { responsible } & 1 & 2 & 3 & 4 & 5 & 6 & 7 & 8 & 9 & \text { responsible }\end{array}$

20. To what degree did you believe that it was better to reach some decision, even if you were unsure of the right decision?

Not at all

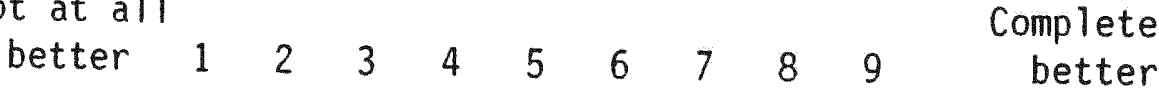

21. Were you, and are you now satisfied with the decision reached by the jury?

not at all

$\begin{array}{lllllllllll}\text { satisfied } & 1 & 2 & 3 & 4 & 5 & 6 & 7 & 8 & 9 & \begin{array}{l}\text { extremely } \\ \text { satisfied }\end{array}\end{array}$

22. How influential were you personally in making the verdict decision?

not at all

influential $1 \quad 2 \quad 2 \quad 3 \quad 4 \quad \begin{array}{llllll}\text { extremely } \\ \text { influential }\end{array}$ 
APPENDIX C

\author{
Case-Specific Pretrial Publicity \\ THE MILWAUKEE JOURNAL \\ WISCONSIN'S LARGEST NEWSPAPER MILWAUKEE, MARCH 24, 1981 \\ DRUG DEALER FOUND DEAD \\ by Dave Droege \\ Staff Writer
}

A Milwaukee man was found dead March 23, 1981. He was shot in the face by a .22 caliber gun.

Dead is Fred Johnson 1229 North

21st Street. He was killed at the residence of Sally Roberts, 5042 North 21 st Street city of Milwaukee.

Milwaukee police have charged

Frank Smith, 28, 3412 North Seventh Street., first degree murder. He is being held in Milwaukee County Jail on 20,000 bond.

Police went to Roberts' house sometime in the evening hours after being called by Sally Roberts' mother. Johnson was dead at the scene. He was found lying in the alley behind Roberts' apartment with a bullet wound to the face said officer overby.

Smith was arrested after Johnson's body was found. Overby did not say what linked Smith with the shooting. Neighbors said they'd seen him "hanging around" with known drug dealers. Smith had been convicted of heroine possession last year. Officers are still looking for witnesses Overby said.

Milwaukee County Coroner, Robert Huntington, has ruled the death homicide. Huntington said Johnson died as a result of being shot in the face with a .22 caliber gun. 
A formal autopsy is being made today Huntington said. He added that the shot struck Johnson in the right side of the face near the nose and traveled through the head ending up at the left brain.

Earlier that day police dispatch received an anonymous tipoff that a drug "deal" might take place. 
MURDER SUSPECT AMONG 10 SUSPECTED

OF DRUG TRAFFICKING

by Dave Droege

Staff Writer

The Milwaukee Grand Jury has indicted Frank Smith for aggravated murder in connection with the March 23, 1981 shooting of a 27 year old city man.

The Grand Jury issued indictments during a 2-day session that ended Tuesday morning.

The indictments are formal charges and do not imply guilt, but the District Attorney's Office says they're confident of getting a conviction. Smith, 28, 3412 North Seventh Street, is charged with the shooting and killing of Fred Johnson. Johnson was killed at the home of Sally Roberts, 5042 North 21st Street. A bloody path led officers to the body located in the alley behind Roberts' apartment. Probable cause of death was a gunshot wound to the face.

Police arrested Smith later that day. The gun used to fire the shot was never found. According to police, Smith's story is weak. Because of Smith's prior drug-related arrests and his known associations with drug traffickers, the police are confident that the aggravated murder charge will be easy to prove. 
FIRST DEGREE MURDER CHARGE GOES TO TRIAL ON JAN. 6

by Dave Droege Staff Writer

The man charged with using a gun to kill Fred Johnson will go on trial in early January in Milwaukee County in Common Pleas Court. Frank Smith, 28, 3412 North Seventh Street, Milwaukee, was found competent to stand trial during a hearing Friday morning in Common Pleas Court.

Smith's trial on a first degree murder charge will start Jan. 6, 1982. Milwaukee police charged Smith after Johnson was slain during the evening hours on March 23, 1981. Johnson was shot in the head by a .22 bullet while sitting in the living room of Sally Roberts' apartment, 5042 North 21st Street, Milwaukee. Johnson was found dead in the alley behind the Roberts' residence.

Smith, who confessed and then retracted his confession just after arrest, has entered pleas of not guilty. He is being held on $\$ 100,000$ bond.

During last Friday's hearing the Milwaukee Prosecutor's Office presented psychiatric reports from the Milwaukee State Hospital for the Criminally Insane and the Madison Diagnostic Center.

Smith's attorney, William Coffee, presented reports for Dr. Robert Mahrer and Dr. Ricardo Girona. Deehre's decision was based on the reports. 
All of the reports can be submitted as evidence in the case, a spokesman for the prosecutor's office said. 
COUNTRY'S FIRST VIDEOTAPED

CRIMINAL TRIAL PLANNED

by Dave Droege

Staff Writer

The jury trial of a
Milwaukee man accused of
shooting another man to death
will be the first videotaped
criminal trial conducted in
Milwaukee County.

Jurors will hear

videotaped testimony from tapes

prepared before the trial, which is tentatively expected to start Jan. 6 .

In an effort to piece together the evidence, the Prosecutor's Office solicited the statements of Sally Roberts, the scene of the shooting, and David Jones, an eyewitness to the slaying. According to the District Attorney, McCann, Roberts told her mother that: "Alice and I were in the kitchen when I heard a shot. I ran into the living room and saw a man lying on the couch and he was bleeding. Frank was standing there. I think they were trying to drag the man out of the house."

The investigating officer said that when he entered the living room of Roberts' apartment he found blood spattered on the couch and floor. there was a path of blood spatters which led from the living room through the dining room and kitchen and out into the backyard. I followed the blood spatters until I found Fred Johnson's body. 
A little while later

David Jones, one of the individuals who had gathered that evening at Sally Roberts' apartment, was arrested. Upon questioning he told the police that: "On March 23, 1981, he was at Sally and Alice Roberts' residence with Frank Smith and Fred Johnson and while the three of them were in the living room, he (David Jones) was sitting in a chair. Fred Johnson was seated on the couch and Frank Smith was standing 8 to 10 feet away from Fred Johnson with a .22 caliber revolver in his hand arguing with Fred Johnson. He saw Frank Smith point the gun at Fred Johnson and after hearing the shot, saw Fred Johnson with lots of blood coming from his face. Frank Smith was upset because Fred Johnson had promised to deliver drugs and had failed to do so. Roberts' house without Frank being present."

He also said that: Earlier that evening, when he, Frank Smith and Fred Johnson were at a different residence, he saw Frank Smith point the revolver at Fred Johnson and heard him threaten to $\mathrm{kill} \mathrm{him}$.

The next day, Frank Smith was arrested. In response to questioning he denied shooting Fred Johnson. He said that: "He, Fred Johnson and David Jones were in the living room of Sally Roberts' residence when he heard a shot and saw Fred Johnson bleeding from his face. He then told them (David 
Jones and Bill Sherman) to get Fred Johnson's body out of the house. At that time David Jones gave him the gun which he carried as the body was removed from the house. They then left the residence in $B i 11$ Sherman's car. He then gave the gun back to David Jones and when David left the car he took the gun with him."

Police say that Smith's record shows drug related arrested in 1979 and 1980. According to one local bar owner, Smith has been asked to leave his establishment several times due to excessive drinking and rough behavior.

Frank Smith was confronted by David Jones in the District Attorney's Office and made no response when David Jones said that he saw Frank Smith shoot Fred Johnson. 
COURT POSTPONES DRUG

RELATED MURDER TRIAL

by Dave Droege

Staff Writer

The trial of Frank Smith, charged with first degree murder, was postponed after a brief hearing Tuesday in Milwaukee County Common Pleas Court. Smith had recently been released from drug rehab.

Smith, 28, 3412 North Seventh Street, Milwaukee, was charged with first degree murder in the March 23 slaying of Fred Johnson. Johnson was found dead in the alley behind Smith's girlfriend's apartment. Johnson had been shot in the face.

No new date has been set for Smith's trial. Smith will be held in Milwaukee County Jail until the trial.

When the case goes to trial, Smith may not have to appear in the courtroom.

Smith's attorneys-William Coffee and William Retert--and the Milwaukee County Prosecutor's Office are considering having testimony in the trial videotaped for the jury, eliminating the use of live witnesses.

David Jones, the State's witness, told police that on March 23, 1981 he was at a residence located at 5042 North 21st Street with the Frank Smith and Fred Johnson. He further stated that while he, Smith, and Johnson were in the living room in Roberts' residence he observed Smith, 
who had a .22 caliber revolver

in his hand, arguing with Fred

Johnson. He further stated that Smith was upset with Fred Johnson because Johnson had been over to Smith's girlfriend's, Sally Roberts, house earlier in the evening without Smith being present. Smith had been arrested twice previously for threatening to kill a former employer and for attempting to murder an unfaithful girlfriend. Smith's defense in both cases was temporary insanity due to drug use. 
DEFENDANT IN MURDER CASE

\section{RETRACTS CONFESSION}

by Dave Droege

Staff Writer

Two Mi lwaukee men, Frank

Smith and David Jones, were arrested on charges of first degree murder on March 23, 1981. Both men, along with several others, had been present when Fred Johnson was shot at the home of Smith's girlfriend. During police interrogation, Smith confessed to the murder saying that he was "out of his head on dope and furious because Johnson had come on to his girl." At the time of his arrest, Smith did not know that Jones also was being held on similar charges. Finding out afterward that the police suspected Jones as well as himself, he withdrew his confession saying that "the drugs and pressure from the police made him confess to a murder that he did not commit." The police polygrapher will administer a lie-detector test to determine whether or not Smith is lying. 
MURDER SUSPECT'S GIRLFRIEND

INCRIMINATES HIM

by Dave Droege

Staff Writer

Frank Smith, 28, 3412 North Seventh Street, Milwaukee was charged with shooting Fred Johnson in the face at his girlfriend's house on March 23 , 1981. Sally, Smith's girlfriend, told police that she and a friend were in the kitchen when she heard a shot. That she ran into the living room and saw a man lying on the couch and he was bleeding. Frank was standing there. Sally said she "thinks he was trying to drag Johnson's body out of the house." She said she was "afraid that Frank would shoot her too." Apparently Sally's fear is based on the knowledge that Smith had been arrested twice before on suspicion of murder. Allegedly Smith had threatened to kill a former employer for failing to authorize a pay raise and before that Smith had attempted to kill an unfaithful girlfriend. Smith's girlfriend is the State's key witness in the trial set for Jan. 6, 1982. 


$$
\text { Judge - Federal Voir Dire }
$$

Ladies and gentlemen I am Judge Moran and what we are about to do is called the voir dire examination. The reason that these questions are asked is not to pry into your personal affairs, that's not really the intent here, it's simply to try to select a jury as impartial as possible.

INTRODUCE COUNSEL

1. Do you understand that the defendant has no burden to prove his innocence?

2. Will you follow the law even though you might personally disagree with it?

3. Do you have any relatives or friends who work in law enforcement?

4. This trial involves allegations of first degree murder against the defendant Frank Smith. Have you, your family or any close acquaintance ever had an experience that might prejudice you?

5. Have you heard or read anything from radio, television, newspapers or the news media about this case?

6. Do you understand that the evidence which you will evaluate in this case will come solely from the witness stand and not from any other source?

7. Do you have any difficulty presuming the defendant innocent now?

8. Will you follow the law as the court gives it to you and thereafter base your verdict on the law and the evidence introduced in this trial?

9. Do you know of any reason why you cannot be fair and impartial at this time?

10. SWEAR THE JURY 


\section{References}

Adams, J. S. (1965). Inequity in social exchange. In L. Berkowitz (Ed.). Advances in experimental social psychology, Vol. 2 (pps. 266-300). New York: Academic Press.

American Bar Association (1978). Standards relating to the administration of criminal justice, fair trial and free press. Chicago: American Bar Association.

Bartlett, F. C. (1932). Remembering: a study in experimental and social psychology. Cambridge: Cambridge University Press.

Berkowitz, L., \& Walster, E. (1976). Equity theory: Toward a general theory of social interaction. In L. Berkowitz (Ed.), Advances in experimental social psychology, Vol. 9. New York: Academic Press.

Bermant, G. (1985). Issues in trial management: Conducting the voir dire examination. In S. M. Kassin and L. S. Wrightsman (Eds.), The psychology of evidence and trial procedure. Beverly Hills, CA: Sage.

Bermant, G. (1977) Conduct of the voir dire examination: Practices and opinions of federal district judges. Washington, DC: Federal Judicial Center.

Broeder, D. W. (1965). Voir dire examinations: An empirical study. Southern California Law Review, 38, 503-528.

Bonora, B., \& Krauss, E. (1979). Jurywork: Systematic techniques. National Jury Project: Oakland, CA.

Bruner, J. S. (1973). Beyond the information given. New York: Norton.

Bruner, J. S., \& Goodman, C. C. (1947). Value and need as organizing factors in perception. Journal of Abnormal Social Psychology, 42 , 33-44.

Buchanan, R. W., Pryor, B., Taylor, K. P., \& Strawn, D. V. (1978). Legal communication: An investigation of juror comprehension of pattern jury instructions. Communication Quarterly, 26, 31-35.

Burnstein, E., \& Vinokur, A. (1975). What a person thinks upon learning he has chosen differently from others. Journal of Experimental 
Social Psychology, 11, 412-426.

Burnstein, E., \& Vinokur, A. (1977). Persuasive argumentation andsocial comparison as determinants of attitude polarization. Journal of Experimental Social Psychology, 4, 66-94.

Carroll, J. S., Kerr, N. L., Alfini, J. J., Weaver, F. M., MacCoun, R. J., \& Feldman, V. (1986). Free press and fair trial: The role of behavioral research. Law and Human Behavior, 10, 187-201.

Charrow, R. R., \& Charrow, V. R. (1979). Making legal language understandable: A psycholinguistic study of jury instructions. Columbia Law Review, 79, 1306-1374.

Costanini, E., \& King, J. (1980/1981). The partial juror: Correlates and causes of prejudgment. Law and Society Review, 15, 9-40.

Cutler, B. L., Narby, D., \& Moran, G. (1990). Unpublished manuscript.

Darley, J. M., \& Fazio, R. H. (1980). Expectancy confirmation processes arising in the social interaction sequence. American Psychologist, 35, 867-881.

De Luca, A. J. (1979). Tipping the scales of justice: The effects of pretrial publicity. Unpublished master's thesis, Iowa State University, Ames.

Deutsch, M. \& \& Gerard, H. B. (1955) A study of normative and informational social influence upon individual judgment. Journal of Abnormal and Social Psychology, 51, 629-636.

Dexter, H. R., Penrod, S. D., \& Linz, D. G. (1988). Unpublished manuscript.

Doob, A. N., \& Kirshenbaum, H. M. (1973). Some empirical evidence on the effect of 5.12 of the Canada evidence act upon an accused. The Criminal Law Quarterly, 15, 88-95.

Elwork, A., Sales, B. D., \& Alfini, J. J. (1977). Juridic decisions: In ignorance of the law or in light of it? Law and Human Behavior, 1, 163-189.

Festinger, L. (1957). A theory of cognitive dissonance. Evanston, IL.: Row, Peterson. 
Greene, E., \& Loftus, E. F. (1985). When crimes are joined at trial. Law and Human Behavior, 9, 193-207.

Hastie, R. (1980). Memory for behavioral information that confirms or contradicts a personality impression. In R. Hastie, T. M. 0strom, E. B. Ebbesen, R. S. Wyer, Jr., D. L. Hamilton, and D. E. Carlston (Eds.). Person memory: the cognitive basis of social perception. Hillsdale, NJ: Erlbaum.

Heider, F. (1958). The psychology of interpersonal relations. New York: Wiley.

Hennenberg, M. C., \& DeVan, M. R. (1987). Conducting a defense jury voir dire through the judge in federal district court. Champion (March).

Hvistendah1, J. K. (1979). The effect of placement of biasing information. Journalism Quarterly, 56, 863-865.

Horowitz, I. A., Bordens, K. S., \& Feldman, M. S. (1980). A comparison of verdicts obtained in separate and joined criminal trials. Journal of Applied Social Psychology, 10, 444-456.

Irvin V. Dowd, 366 U.S. 717 (1961).

James, W. (1890). Principles of psychology. New York: Holt.

Jones, E. E., \& Davis, K., E. (1965). From acts to dispositions: The attribution process in person perception. In L. Berkowitz (Ed.), Advances in experimental social psychology, Vol. 2. New York: Academic Press.

Jones, S. E. (1987). Judge-versus attorney-conducted voir dire: An empirical investigation of juror candor. Law and Human Behavior, 11. 131-146.

Kagehiro, D. K., \& Stanton, W. C. (1985). Legal vs. quantitative definitions of standards of proof. Law and Human Behavior, 9 , $159-178$.

Kassin, S. M. (1985, August). Juries and the doctrine of entrapment. Paper presented at the meeting of the American Psychological Association, Los Angeles. 
Kassin, S. M., \& Wrightsman, L. S. (1980). Prior confessions and mock juror verdicts. Journal of Applied Social Psychology, 10, 133146.

Kassin, S. M., \& Wrightsman, L. S. (1981). Coerced confessions, judicial instruction, and mock juror verdicts. Journal of Applied Social Psychology, 11, 489-506.

Kassin, S. M. , \& Wrightsman, L. S. (1983). The construction and validation of a juror bias scale. Journal of Research in Personality, 17, 423-442.

Kassin, S. M., \& Wrightsman, L. S. (1985). Confession evidence. In S. M. Kassin and L. S. Wrightsman (Eds.), The psychology of evidence and trial procedure. Beverly Hills, CA: Sage.

Kelley, H., H. (1967). Attribution theory in social psychology. In D. L. Vine (Ed.), Nebraska symposium on motivation. Lincoln, NB: University of Nebraska Press.

Kelley, H., H. (1973). The processes of causal attribution. American Psychologist, 28, 107-128.

Kiesler, C. (1971). The psychology of commitment. New York: Academic Press.

Kiesler, C., \& Sakumura, J. (1966). A test model for commitment. Journal of Personality and Social Psychology, 3 , 349-353.

Kline, F. G., \& Jess, P. H. (1966). Prejudicial publicity: Its effects on law school mock juries. Journalism Quarterly, 43, 113116.

Linz, D. G. (1989). Personal communication.

Lord, C. G., Ross, L., \& Lepper, M. R. (1979). Biased assimilation and attitude polarization: The effects of prior theories on subsequently considered evidence. Journal of Personality and Social Psychology, 37, 2098-2109.

McGuire, W. J. (1961). The effectiveness of supportive and refutational defenses in immunizing and restoring beliefs against persuasion. Sociometry, 24, 184-197. 
McGuire, W. J. (1964). Inducing resistance to persuasion. In L. Berkowitz (Ed.), Advances in experimental social psychology. Vol. 1 (pps. 191-229). New York: Academic Press.

Moran, G., \& Cutler, B. L. (in press). The prejudicial impact of pretrial publicity. Journal of Applied Social Psychology.

Moran, G., \& Cutler, B. L. (1989, August 12). Dispositional predictors of criminal case verdicts. In B. L. Cutler (Chair) Contemporary psychological and legal perspectives on jury selection. Symposium presented at the $97 \mathrm{th}$ annual meeting of the American Psychological Association, New Orleans, LA.

Moran, G., \& Comfort, J. C. (1982). Scientific juror selection: Sex as a moderator of demographic and personality predictors of impaneled felony juror behavior. Journal of Personality and Social Psychology, 43, 1052-1063.

Moran, G., Cutler, B. L., \& Loftus, E. F. (1990). Jury selection in major controlled substance trials: The need for extended voir dire. Forensic Reports, 3 , 331-348.

Murphy v. Florida, 421 U.S. 794 (1975).

Neisser, U. (1976). Cognition and reality: principles and implications of cognitive psychology. San Francisco: Freeman.

Nietzel, M. T., \& Dillehay, R. C. (1982). The effects of variations in voir dire proceedings in capital murder trials. Law and Human Behavior, $\underline{6}, 1-13$.

Nietzel, M. T., \& Dillehay, R. C. (1986). Psychological consultation in the courtroom. New York: Pergamon.

Nisbett, R., \& Borgida, E., Cranda11, R., \& Reed, H. (1976). Popular induction: Information is not necessarily informative. In J. S. Carroll, \& J. W. Payne (Eds.), Cognition and social behavior. Hillsdale, NJ: Erlbaum.

Nisbett, R. E., \& Wilson, T. D. (1977). Telling more than we can know: Verbal reports on mental processes. Psychological Review, 84, 231-259. 
O'Connel1, P. D. (1988). Pretrial publicity, change of venue, public opinion polls--A theory of procedural justice. University of Detroit Law Review, 65, 169-197.

Otto, A. L., Penrod, S. D., \& Hirt, E. R. (1990). Unpublished manuscript.

Padawer-Singer, A. M., Singer, A., \& Singer, B. (1974). Voir dire by two lawyers: An essential safeguard. Judicature, 57, 386-391.

Padawer-Singer, A., \& Barton, A. H. (1975). Free press, fair trial. In R. J. Simon (Ed.), The jury system: A critical analysis. Beverly Hills, CA: Sage.

Pennington, N., \& Hastie, R. (1986). Evidence evaluation in complex decision making. Journal of Personality and Social Psychology. 51, 242-258.

Pennington, N., \& Hastie, R. (1990). Practical implication of psychological research on juror and jury decision making. Personality and Social Psychology Bulletin, 16, 90-105.

Penrod, S. D., \& Cutler, B. L. (1987). Assessing the competence of juries. In I. B. Weiner \& A. K. Hess (Eds.). The handbook of forensic psychology (pp. 135-163). Springfield, IL: Charles C.Thomas.

Penrod, S., \& Linz, D. (1984). Voir dire: Uses and abuses. In M. F. Kaplan (Ed.). The impact of social psychology on procedural justice (pp. 135-163). Springfield, IL: Charles C. Thomas.

Rideau V. Louisiana, 373 U.S. 723 (1963).

Ross, L. (1977). The intuitive psychologist and his shortcomings: distortions in the attribution process. In L. Berkowitz (Ed.), Advances in experimental social psychology, Vol. 10. New York: Academic Press.

Saks, M. J. (1989). Legal policy analysis and evaluation. American Psychologist, 44, 1110-1117.

Schmolesky, J. M., Cutler, B. D., \& Penrod, S. D. (1988). Presumption instructions and juror decision making. Forensic Reports, 1 , 165-192. 
Severance, L. J., \& Loftus, E. F. (1981/1982). Improving the ability of jurors to comprehend and apply criminal jury instructions. Law and Society Review, 17, 153-197.

Sheppard V. Maxwell, 384 U.S. 333 (1966).

Sherif, M. (1935). A study of some social factors in perception. Psychological Archives, 187, 1-111.

Simon, R. J. (1966). Murder, juries, and the press. Trans-Action (May-June), 64-65.

Snyder, M. (1982). When believing means doing: Creating links between attitudes and behavior. In M. Zanna, E. T. Higgins and C. P. Herman (Eds.), Consistency in social behavior. Hillsdale NJ: Erlbaum.

Snyder, M., \& Uranowitz, S. W. (1978). Reconstructing the past: Some cognitive consequences of person perception. Journal of Personality and Social Psychology, 36, 941-950.

Snyder, M., Tanke, E. D., \& Berscheid, E. (1977). Social perception and interpersonal behavior: On the self-fulfilling nature of social stereotypes. Journal of Personality and Social Psychology, 35, 656-666.

Snyder, M., \& Swann, W. B., Jr. (1978a). Hypothesis testing processes in social interaction. Journal of Personality and Social Psychology, 36, 1202-1212.

Sue, S., Smith, R. E., \& Gilbert, R. (1974). Biasing effect of pretrial publicity on judicial decisions. Journal of Criminal Justice, $3,163-171$.

Sue, S., Smith, R., \& Pedroza, G. (1975). Authoritarianism, pretrial publicity and awareness of bias in simulated jurors. Psychological Reports, 37, 1299-1302.

Strawn, D. U., \& Buchanan, R. W. (1976). Jury confusion: A threat to justice. Judicature, 59, 478-483.

Swain V. Alabama, 380 U.S. 202. (1965). 
Tanford, S., \& Penrod, S. (1984). Social inference processes in juror judgments of multiple-offense trials. Journal of Personality and Social Psychology, 47, 749-765.

Tanford, S., \& Penrod, S. (1982). Biases in trials involving defendants charged with multiple offenses. Journal of Applied Social Psychology, 12, 453-480.

Tanford, S., \& Penrod, S., \& Collins, R. (1985). Decision making in joined criminal trials: The influence of charge similarity, evidence similarity, and limiting instructions. Law and Human Behavior, 9 , 319-337.

Tans, M., \& Chaffee, S. (1966). Pretrial publicity and juror prejudice. Journalism Quarterly, 43, 647-654.

Taylor, S. E. (1982). A categorization approach to stereotyping. In D. L. Hamilton (Ed.), Cognitive processes in stereotyping and intergroup behavior. Hillsdale, NJ: Erlbaum.

Taylor, S. E., \& Crocker, J. (1980). Schematic bases of social information processing. In E. T. Higgins, C. P. Herman, \& M. P. Zanna (Eds.), Social cognition: The Ontario symposium on personality and social psychology. Hillsdale, N.J.: Eribaum.

Taylor, S. E., \& Fiske, S. T. (1978). Salience, attention, and attribution: Top of the head phenomena. In L. Berkowitz (Ed.), Advances in experimental social psychology (Vol. 11). New York: Academic Press.

Taylor, S. E., Fiske, S. T., Etcoff, N. L., \& Ruderman, A. J. (1978). Categorical and contextual bases of person memory and stereotyping. Journal of Personality and Social Psychology, 36, 778-793.

Tetlock, P. E. (1983). Accountability and the perseverance of first impressions. Social Psychology Quarterly, 46, 285-292.

Thompson, W. C., \& Schumann, E. L. (1987). Interpretation of statistical evidence in criminal trials: The prosecutor's fallacy and the defense attorney's fallacy. Law and Human Behavior, 11, $167-187$.

Tversky, A., \& Kahneman, D. (1974). Judgement under uncertainty: 
Heuristics and biases. Science, 185, 1124-1131.

United States V. Blanton, (1978).

United States V. Dellinger, 475 F.2d 340, 368 (7th Cir. 1972).

Vidmar, N., \& Judson, J. (1981). The use of social sciences in a change of venue application. Canadian Bar Review, 59, 76-102.

Wilcox, W., \& Mccombs, M. (1967). Crime story elements and fair trial/free press. Unpublished paper, Berkeley, University of California.

Wyer, R. S., Jr. (1974). Cognitive organization and change: An information processing approach. Potomac, Md.: Erlbaum.

Wyer, R. S., Jr. (1975a). The role of probabilistic and syllogistic reasoning in cognitive organization and social change. In $M$. Kaplan and S. Schwartz (Eds.). Human judgment and decision processes. New York: Academic Press.

Wyer, R. S., Jr. (1976). Effects of previously formed beliefs on syllogistic inference processes. Journal of Personality and Social Psychology, 33, 307-316.

Wyer, R. S., Jr, \& Srull, T. K. (1980). The processing of social stimulus information: A conceptual integration. In R. Hastie, T. M. Ostrom, E. B. Ebbesen, R. S. Wyer, Jr., D. L. Hamilton, and D. E. Carlston (Eds.), Person memory: The cognitive basis of social perception. Hillsdale, NJ: Erlbaum.

Zanzola, L. (1977). Effects of pretrial publicity on the verdicts of jurors and juries. Unpublished study, Department of Psychology, Northern Illinois University.

Zeisel, H., \& Diamond, S. S. (1978). The effect of peremptory challenges on jury and verdict: An experiment in a Federal District Court. Stanford Law Review, 30, 491-531. 


\section{CURRICULUM VITAE}

\section{Hedy Red Dexter}

August 6, 1990

Department of Psychology HUMBOLDT STATE UNIVERSITY Arcata, CA 95521

Office: (707) 826-3755
2037B Blake Road

McKinleyville, CA 95521

Home: (707) 839-0337

SS\#: $378-52-6847$

Education

Ph.D. July 31, 1990; Florida International University, North Miami, FL

Major: Applied Social Psychology

Dissertation Title: In Search of the Fair Jury: Does Extended Voir Dire Remedy the Effects of Pretrial Publicity

M.S. 1986 The College of William and Mary, Williamsburg, VA Major: General Psychology

Masters Thesis Title: Motivated Distortion: Effects of Situational and Personal Relevance on Attributions of Responsibility to Victims and Perpetrators

B.S. 1984 University of North Carolina at Chapel Hill, Chapel Hill, NC Major: Dental Auxiliary Teacher Education Minor: Twentieth Century American Literature Honors Degree

A.S. 1974 University of Detroit, School of Dentistry, Detroit, MI

Major: Dental Hygiene

Scholarly Publications

Cutler, B. L., Dexter, H. R., \& Penrod, S. D. (in press). Nonadversarial methods for improving juror sensitivity to eyewitness evidence. Journal of Applied Social

Psychology. 
Cutler, B. L., Penrod, S. D., \& Dexter, H. R. (1990). Juror sensitivity to eyewitness identification evidence. Law and Human Behavior, 14, 185-191.

Cutler, B. L., Dexter, H. R., \& Penrod, S. D. (1989). Expert testimony and jury decision making: An empirical analysis. Behavioral Sciences and the Law, $I, 215-225$.

Cutler, B. L., Penrod, S. D., \& Dexter, H. R. (1989). The eyewitness, the expert psychologist, and the jury. Law and Human Behavior, 13, 311-332.

Shaver, K. G., \& Dexter, H. R. (1985). Personality and social psychology at NIMH: A brief guide for investigators. Contemporary Social Psychology, 11, $53-57$.

\section{Manuscripts under Review}

Otto, A. M., Dexter, H. R., \& Penrod, S. D. Pretrial publicity and jury decisionmaking: Experimental studies with actual cases. Journal of Applied Psychology.

Dexter, H. R., \& Cutler, B. L. In search of the fair jury: Does extended voir dire remedy the effects of pretrial publicity? Journal of Personality and Social Psychology.

Cutler, B. L., Penrod, S. D., \& Dexter, H. R. How does the "battle of the eyewitness experts' affect the judgments of jurors? Journal of Applied Psychology.

Dexter, H. R., Penrod, S. D., Linz, D., Saunders, D. Blaming female victims after exposure to sexually violent films: The effects of victim-observer similarity, situational relevance and mass media induced emotional arousal. Journal of Personality and Social Psychology.

\section{Conference Presentations}

Penrod, S. D., Dexter, H. R., 0tto, A. (1990, March). The prejudicial effects of pretrial publicity on a fraternity tried as racists. Paper presented at the meeting of the American Psychology and Law Society, Williamsburg.

Linz, D. G., \& Dexter, H. R. (1989, August). Exposure to mass media sexual violence and judgments about sexual abuse victims. Paper presented at the meeting of the 
abuse victims. Paper presented at the meeting of the American Psychological Association, New Orleans.

Dexter, H. R. (1989, April). Is Kate a socialized victim or personal agent: A social psychological interpretation. Paper presented at the meeting of the Comparative Drama Conference XIII, Gainsville.

Dexter, H. R., Cutler, B. L., \& Penrod, S. D. (1988, August). The influence of expert testimony on decisions from experienced and inexperienced jurors. Paper presented at the meeting of the American Psychological Association, Atlanta.

Dexter, H. R., Cutler, B. L., \& Penrod, S. D. (1988, August). Influence of expert testimony on decisions of experienced jurors. Paper presented at the meeting of the American Psychological Association, Atlanta.

Dexter, H. R., Penrod, S. D., \& Cutler, B. L. (1988, May). Use of expert psychological testimony during jury deliberation. Paper presented at the meeting of the Midwestern Psychological Association, Chicago.

Dexter, H. R., Penrod, S. D., \& Cutler, B. L. (1988, May). Will a "battle of the experts" inform or confuse the jury? Paper presented at the meeting of the Midwestern Psychological Association, Chicago.

Cutler, B. L., Penrod, S. D., \& Dexter, H. R. (1988, March). The eyewitness, the expert psychologist, the judge, and the jury. Paper presented at the meeting of the American Psychology-Law Society, Miami Beach.

Dexter, H. R., Linz, D. G., Penrod, S. D., \& Saunders, D. (March, 1988). Exposure to media violence and the blaming of assault victims. American Psychology and Law Society, Miami.

Cutler, B. L., Penrod, S. D., \& Dexter, H. R. (1987, August). Expert testimony on eyewitness identification. Paper presented at the meeting of the American Psychological Association, New York.

Dexter, H. R., Cutler, B. L., \& Penrod, S. D. (1987, May). Juror decisionmaking in eyewitness identification cases: 
Evidence from eligible jurors. Paper presented at the meeting of the Midwestern Psychological Association, Chicago.

Dexter, H. R., \& Shaver, K. G. (Apri1, 1986). Victim's contribution to an accident: Responsibility attributions to victims and perpetrators. Paper presented at the meeting of the Eastern Psychological Association, New York.

Dexter, H. R., \& Shaver, K. G. (August, 1985). Women's performance and women's place: A natural experiment. Paper presented at the meeting of the American Psychological Association, Los Angeles.

Professional History

Aug to Dec 1990

Adjunct Instructor Introductory Psychology

Personality Psychology

Feminist Theory

Humboldt State University

May to August 1990

Adjunct Instructor

Introductory Psychology

Personality Theory

Florida International University

Experimental Psychology

St. Thomas University

Aug, 1989 to May 1990

Adjunct Instructor

Social Psychology

Introductory Psychology

Humboldt State University

June to August 1989

Adjunct Instructor

Theories of Personality

Psychology of Women

Department of Psychology

Florida International University

Aug. to June 1989

Adjunct Instructor Introductory Psychology

Department of Psychology

Florida International University 
Jan. to May 1988

Teaching Assistant

Introductory Psychology

Department of Psychology

University of Wisconsin-Madison

June 1986 to Dec. 1987 Research Assistant

Department of Psychology (S.

Penrod)

University of Wisconsin-Madison

Teaching Assistant

Social Psychology (S. Penrod)

Psychology and Law (S. Penrod)

Department of Psychology

University of Wisconsin-Madison

Sept. 1984 to May 1986 Research Assistant

Department of Psychology (Michael

Rohrbaugh)

The College of William and Mary

Teaching Assistant

The College of William and Mary

Lab instructor in Experimental

Methods

Lab instructor in Elementary

Statistics

Lab instructor in Comparative

Psychology

Experimental Social Psychology

Advanced General Psychology

(senior thesis students)

Jan. 1984 to June 1984 Teaching Intern

University of Maryland, School of

Dentistry

Clinical Methods

Behavior Modification in Patient

Education

Sept. 1983 to Dec. 1983 Teaching Intern

University of North Carolina at Chapel Hill, School of Dentistry 